\title{
Spermiogenesis and spermatozoon ultrastructure in basal polyopisthocotylean monogeneans, Hexabothriidae and Chimaericolidae, and their significance for the phylogeny of the Monogenea
}

\author{
Jean-Lou Justine $^{1, *}$ and Larisa G. Poddubnaya ${ }^{2}$ \\ ${ }^{1}$ Institut Systématique Évolution Biodiversité (ISYEB), Muséum National d'Histoire Naturelle, CNRS, Sorbonne Université, \\ EPHE, 57 rue Cuvier, CP 51, 75005 Paris, France \\ 2 I. D. Papanin Institute for Biology of Inland Waters, Russian Academy of Sciences, 152742 Borok, Yaroslavl, Russia
}

Received 27 November 2017, Accepted 24 January 2018, Published online 13 February 2018

\begin{abstract}
Sperm ultrastructure provides morphological characters useful for understanding phylogeny; no study was available for two basal branches of the Polyopisthocotylea, the Chimaericolidea and Diclybothriidea. We describe here spermiogenesis and sperm in Chimaericola leptogaster (Chimaericolidae) and Rajonchocotyle emarginata (Hexabothriidae), and sperm in Callorhynchocotyle callorhynchi (Hexabothriidae). Spermiogenesis in $C$. leptogaster and $R$. emarginata shows the usual pattern of most Polyopisthocotylea with typical zones of differentiation and proximo-distal fusion of the flagella. In all three species, the structure of the spermatozoon is biflagellate, with two incorporated trepaxonematan 9+ "1" axonemes and a posterior nucleus. However, unexpected structures were also seen. An alleged synapomorphy of the Polyopisthocotylea is the presence of a continuous row of longitudinal microtubules in the nuclear region. The sperm of $C$. leptogaster has a posterior part with a single axoneme, and the part with the nucleus is devoid of the continuous row of microtubules. The spermatozoon of $R$. emarginata has an anterior region with membrane ornamentation, and posterior lateral microtubules are absent. The spermatozoon of $C$. callorhynchi has transverse sections with only dorsal and ventral microtubules, and its posterior part shows flat sections containing a single axoneme and the nucleus. These findings have important implications for phylogeny and for the definition of synapomorphies in the Neodermata. We point out a series of discrepancies between actual data and interpretation of character states in the matrix of a phylogeny of the Monogenea. Our main conclusion is that the synapomorphy "lateral microtubules in the principal region of the spermatozoon" does not define the Polyopisthocotylea but is restricted to the Mazocraeidea.
\end{abstract}

Keywords: Monogenea, phylogeny, sperm ultrastructure

Résumé-Spermiogenèse et ultrastructure des spermatozoïdes chez les Monogènes Polyopisthocotylea basaux Hexabothriidae et Chimaericolidae, et leur signification pour la phylogénie des Monogenea. L'ultrastructure des spermatozoïdes fournit des caractères morphologiques utiles pour comprendre la phylogénie; aucune étude n'était disponible pour deux branches basales des Polyopisthocotylea, les Chimaericolidea et des Diclybothriidea. Nous décrivons ici la spermiogenèse et le spermatozoïde chez Chimaericola leptogaster (Chimaericolidae) et Rajonchocotyle emarginata (Hexabothriidae), et le spermatozoïde chez Callorhynchocotyle callorhynchi (Hexabothriidae). La spermiogenèse chez C. leptogaster et $R$. emarginata montre le schéma habituel de la plupart des Polyopisthocotylea avec une zone de différenciation typique et une fusion proximo-distale des flagelles. Chez les trois espèces, la structure du spermatozoïde est biflagellée, avec deux axonèmes incorporés de type Trepaxonemata $9+$ "1" et un noyau postérieur. Cependant, des structures inattendues ont également été observées. Une synapomorphie présumée des Polyopisthocotylea est la présence d'une rangée continue de microtubules longitudinaux dans la région nucléaire. Le spermatozoïde de $C$. leptogaster a une partie postérieure avec un seul axonème, et la partie avec le noyau est dépourvue de la rangée continue de microtubules. Le spermatozoïde de $R$. emarginata a une région antérieure avec ornementation membranaire et les microtubules postérieurs latéraux sont absents. Le spermatozoïde de

\footnotetext{
*Corresponding author: justine@mnhn.fr
} 


\begin{abstract}
C. callorhynchi a des coupes transversales montrant seulement des microtubules dorsaux et ventraux, et sa partie postérieure présente des coupes plates contenant un seul axonème et le noyau. Ces observations ont des implications importantes pour la phylogénie et la définition des synapomorphies des Neodermata. Nous signalons une série de divergences entre les données réelles et l'interprétation des états de caractères dans la matrice d'une phylogénie des Monogenea. Notre conclusion principale est que la synapomorphie «microtubules latéraux dans la région principale du spermatozoïde » ne définit pas les Polyopisthocotylea mais est limitée aux Mazocraeidea.
\end{abstract}

\section{Introduction}

Sperm ultrastructure has been used as a source of significant characters to elucidate phylogenetic relationships in the Platyhelminthes [20,21], and especially in the parasitic Platyhelminthes or Neodermata. This was the case for the Neodermata as a whole [35,39,42], the Cestoda [2,29,41,67], the Digenea $([6,39]$ and many recent references, e.g. $[5,7,8,73])$ and the Monogenea [12-14,22,34,39,46].

In the Monogenea, the Monopisthocotylea and the Polyopisthocotylea have each been considered to bear respective sperm synapomorphies [34], but no spermatological character has been found to unite the two groups [40].

The Monopisthocotylea have revealed important variations of sperm structure, which led to the recognition of several synapomorphies $[34,39,42]$ that were used in combination with other morphological characters to build phylogenies $[12,14]$. In contrast, the Polyopisthocotylea show a relatively uniform sperm morphology [34,39] with the significant exception of the Diplozoidae with an aberrant aflagellate spermatozoon [47]; the latter has been considered to be related to the exceptional biology of fertilization in diplozoids and especially the absence of sperm competition $[39,47]$.

The Polyopisthocotylea include, in modern classifications [26], four orders: the Polystomatidea, Chimaericolidea, Diclybothriidea and Mazocraeidea. The spermatozoon and sometimes spermiogenesis ultrastructure are documented in several species of the Polystomatidae, in one species of Sphyranuridae (Polystomatidea), and in many families belonging to the Mazocraeidea (Table 1). However, no information was available for the Chimaericolidea and Diclybothriidea. Since the Chimaericolidea or these two orders were considered basal to the Mazocraeidea in both morphological [12] and molecular [32,75,78] analyses, missing data on sperm structure in these orders was a significant knowledge gap of sperm structure in Polyopisthocotylea, and even of the Neodermata as a whole.

In this paper we present, for the first time, observations on two species of the family Hexabothriidae (Diclybothriidea) and one of the family Chimaericolidae (Chimaericolidea), thus filling the gaps in our knowledge of sperm ultrastructure in the Monogenea. These observations complement previous studies on the tegument [88], attachment organs [84,85], reproductive organs [83,87], and digestive system [86] of the same species.

\section{Material and Methods}

For electron microscopy, adult specimens of three polyopisthocotylean monogeneans were recovered from the gills of naturally infected cartilaginous fishes: Chimaericola leptogaster (Leuckart, 1830) (Chimaericolidae) from the chimaera (rabbit fish) Chimaera monstrosa Linnaeus, 1758 (Holocephali), Rajonchocotyle emarginata (Olsson, 1876) (Hexabothriidae) from the thorny (starry) ray Amblyraja radiata (Donovan, 1808) (Elasmobranchii), and Callorhynchocotyle callorhynchi (Manter, 1955) (Hexabothriidae) from the chimaera (Cape elephant fish) Callorhynchus capensis Duméril, 1865 (Holocephali). The first two were collected in the Norwegian Sea off Troms $\varnothing$, Norway, and the latter was from the Southeast Atlantic off St Helena Bay on the western coast of South Africa. Live specimens of all three monogenean species were fixed using $3 \%$ glutaraldehyde in $0.1 \mathrm{M}$ sodium cacodylate buffer $(\mathrm{pH}$ 7.2) for 20 days at $5{ }^{\circ} \mathrm{C}$, rinsed four times for $20 \mathrm{~min}$ in the same buffer and post-fixed in $1 \%$ osmium tetroxide for $1 \mathrm{~h}$. For ultrathin studies, samples were then dehydrated in a graded series of ethanol and acetone, and embedded in a mixture of Araldite and Epon. Ultrathin sections (70$90 \mathrm{~nm}$ in thickness) were stained with uranyl acetate and lead citrate, and examined using a JEOL-JEM-1011 transmission electron microscope operating at $80 \mathrm{kV}$ [86].

Observations with the electron microscope were performed by LGP; interpretation and choice of micrographs to be included in this study were done by JLJ.

All transverse sections of spermatozoa and spermatids in the figures, with a few exceptions when several sections are together in a micrograph, are orientated with the mitochondrion at the bottom, thus following the arbitrary convention of Sato, Oh \& Sakoda [97] of mitochondrion as "ventral". Longitudinal sections of spermatids are orientated with the anterior part at the top, i.e., for the zone of differentiation, the arched membranes at the top, and with the free flagella and the median cytoplasmic process at the bottom [35,39]. Longitudinal schematic drawings of spermatozoa are oriented with the centrioles at the top and the nucleus at the bottom, since neodermatan spermatozoa are "inverted" in comparison with most phyla $[1,39]$.

\section{Results}

\section{Spermiogenesis in the chimaericolid Chimaericola leptogaster (Figures 1 and 2)}

Spermiogenesis involves the formation of a protuberance on each spermatid, termed zone of differentiation. The early zone of differentiation is visible as a small protuberance which is close to the extremity of the nucleus. An intercentriolar body is perpendicular to the cell membrane; the membrane shows peripheral microtubules (Figure 1A). 
Table 1. Studies of sperm ultrastructure in the Polyopisthocotylea.

\begin{tabular}{|c|c|c|c|c|}
\hline $\begin{array}{l}\text { Family } \\
\text { (Alpha. order) }\end{array}$ & $\begin{array}{l}\text { Genus, species, author, } \\
\text { and host }\end{array}$ & $\begin{array}{l}\text { Sperm } \\
\text { reference }\end{array}$ & $\begin{array}{l}\text { "Polyopisthocotylean" } \\
\text { structure of sperm ** }\end{array}$ & Details $^{* *}$ \\
\hline Axinidae & $\begin{array}{l}\text { Axine sp. (ex Hemirhamphus } \\
\text { brasiliensis) }\end{array}$ & {$[55]$} & no & $\begin{array}{l}\text { Only two micrographs; no } \\
\text { lateral microtubules }\end{array}$ \\
\hline Chauhaneidae & $\begin{array}{l}\text { Pseudomazocraes } \text { cf. } \\
\text { monsivaisae }\end{array}$ & {$[55]$} & Polyopisthocotylean & $\begin{array}{l}\text { Typical structure; extremity } \\
\text { with nucleus + single axoneme }\end{array}$ \\
\hline Diclidophoridae & $\begin{array}{l}\text { Diclidophora merlangi (Kuhn } \\
\text { in Nordmann, 1832) Krøyer, } \\
1851\end{array}$ & {$[27]$} & Polyopisthocotylean & $\begin{array}{l}\text { Includes spermiogenesis; single } \\
\text { micrograph shows typical } \\
\text { structure }\end{array}$ \\
\hline Diclidophoridae & $\begin{array}{l}\text { Diclidophora merlangi (Kuhn } \\
\text { in Nordmann, 1832) Krøyer, } \\
1851\end{array}$ & {$[70]$} & Polyopisthocotylean & $\begin{array}{l}\text { Single micrograph shows typical } \\
\text { structure }\end{array}$ \\
\hline Diclidophoridae & Diclidophora sp. & {$[105]$} & Polyopisthocotylean & $\begin{array}{l}\text { Only two micrographs, but } \\
\text { typical sections of spermatozoa }\end{array}$ \\
\hline Diclidophoridae & $\begin{array}{l}\text { Choricotyle chrysophryi Van } \\
\text { Beneden \& Hesse, } 1863 \text { [as } \\
\text { Choricotyle pagelli] }\end{array}$ & {$[105]$} & Polyopisthocotylean & A single micrograph \\
\hline Diplozoidae & $\begin{array}{l}\text { Diplozoon sp.? [as Diplozoon } \\
\text { gracile] }\end{array}$ & {$[39,48]$} & Aberrant & $\begin{array}{l}\text { No axonemes; numerous parallel } \\
\text { microtubules }\end{array}$ \\
\hline Discocotylidae & $\begin{array}{l}\text { Discocotyle sagittata (Leuckart, } \\
1842 \text { ) }\end{array}$ & [19] & Polyopisthocotylean & $\begin{array}{l}\text { Includes spermiogenesis; } \\
\text { crescent-shaped nucleus; lateral } \\
\text { flange }\end{array}$ \\
\hline Gastrocotylidae & Pricea multae Chauhan, 1945 & {$[110]$} & Polyopisthocotylean & $\begin{array}{l}\text { Includes spermiogenesis; typical } \\
\text { section; lateral flange }\end{array}$ \\
\hline Gastrocotylidae & Gastrocotyle sp. & [99] & Polyopisthocotylean & $\begin{array}{l}\text { Includes spermiogenesis; no } \\
\text { section with nucleus and both } \\
\text { axonemes, but sections with } \\
\text { nucleus and single axoneme have } \\
\text { the lateral microtubules }\end{array}$ \\
\hline Gotocotylidae & $\begin{array}{l}\text { Gotocotyla acanthura (Parona } \\
\text { \& Perugia, 1896) Meserve, } \\
1938 \text { (as Gotocotyla secunda) }\end{array}$ & {$[92]$} & dubious & $\begin{array}{l}\text { Single photograph, without } \\
\text { nucleus section }\end{array}$ \\
\hline Gotocotylidae & $\begin{array}{l}\text { Gotocotyla acanthura (Parona } \\
\text { \& Perugia, 1896) Meserve, } \\
1938\end{array}$ & {$[56]$} & Polyopisthocotylean & $\begin{array}{l}\text { Typical polyopisthocotylean } \\
\text { structure with additional } \\
\text { undulating membrane }\end{array}$ \\
\hline Heteraxinidae & $\begin{array}{l}\text { Cemocotyle sp. (ex Caranx } \\
\text { crysos) }\end{array}$ & {$[58]$} & Polyopisthocotylean & Single micrograph, but typical \\
\hline Heteraxinidae & $\begin{array}{l}\text { Heteraxine sp. (ex } \\
\text { Scomberomorus tritor) }\end{array}$ & {$[58]$} & Polyopisthocotylean & Several micrographs, typical \\
\hline Heteraxinidae & $\begin{array}{l}\text { Heteraxinoides sp. (ex } \\
\text { Pomadasys jubelini) }\end{array}$ & {$[58]$} & dubious & $\begin{array}{l}\text { Single photograph, not in region } \\
\text { of nucleus }\end{array}$ \\
\hline Heteraxinidae & $\begin{array}{l}\text { Gonoplasius sp. }(\mathrm{ex} \\
\text { Pseudocaranx dentex })\end{array}$ & {$[94]$} & Polyopisthocotylean & Includes spermiogenesis \\
\hline Hexabothriidae & $\begin{array}{l}\text { Erpocotyle catenulata } \\
\text { (Guberlet, 1933) }\end{array}$ & {$[105]$} & Polyopisthocotylean & $\begin{array}{l}\text { Single micrograph with several } \\
\text { sections; electron-lucent nucleus; } \\
\text { membranes disrupted; not sure } \\
\text { whether lateral microtubules are } \\
\text { present }\end{array}$ \\
\hline Hexostomatidae & $\begin{array}{l}\text { Hexostoma sp. (ex Euthynnus } \\
\text { alleteratus) }\end{array}$ & {$[54]$} & Polyopisthocotylean & $\begin{array}{l}\text { Only three sections shown, but } \\
\text { typical }\end{array}$ \\
\hline Mazocraeidae & $\begin{array}{l}\text { Kuhnia sp. (ex Scomber colias } \\
\text { [as S. japonicus]) }\end{array}$ & {$[55]$} & Polyopisthocotylean & $\begin{array}{l}\text { Only two micrographs; typical } \\
\text { structure, additional cytoplasmic } \\
\text { microtubules }\end{array}$ \\
\hline Microcotylidae & $\begin{array}{l}\text { Metamicrocotyla macracantha } \\
\text { (Alexander, 1954) Koratha, } \\
1955\end{array}$ & {$[9]$} & Polyopisthocotylean & Includes spermiogenesis \\
\hline Microcotylidae & Microcotyle sp. & {$[10]$} & Polyopisthocotylean & $\begin{array}{l}\text { Includes spermiogenesis; only } \\
\text { two micrographs depict typical } \\
\text { sperm structure }\end{array}$ \\
\hline
\end{tabular}


Table 1. (continued).

\begin{tabular}{|c|c|c|c|c|}
\hline $\begin{array}{l}\text { Family } \\
\text { (Alpha. order) }\end{array}$ & $\begin{array}{l}\text { Genus, species, author, } \\
\text { and host }\end{array}$ & $\begin{array}{l}\text { Sperm } \\
\text { reference }\end{array}$ & $\begin{array}{l}\text { "Polyopisthocotylean" } \\
\text { structure of sperm ** }\end{array}$ & Details $^{* *}$ \\
\hline Microcotylidae & $\begin{array}{l}\text { Polylabroides australis } \\
\text { (Murray, 1931) Mamaev \& } \\
\text { Parukhin, } 1976\end{array}$ & {$[95]$} & Polyopisthocotylean & Includes spermiogenesis \\
\hline Microcotylidae & $\begin{array}{l}\text { Pagellicotyle mormyri (Lorenz, } \\
\text { 1878) Mamaev, } 1984 \text { [as } \\
\text { Microcotyle mormyri] }\end{array}$ & {$[104,105]$} & Polyopisthocotylean & Includes spermiogenesis \\
\hline Microcotylidae & $\begin{array}{l}\text { Microcotyle erythrini Van } \\
\text { Beneden \& Hesse, } 1863\end{array}$ & {$[105]$} & Polyopisthocotylean & Includes spermiogenesis \\
\hline Microcotylidae & $\begin{array}{l}\text { Atrispinum sargi (Parona \& } \\
\text { Perugia, 1890) Euzet \& } \\
\text { Maillard, 1974 [as At. "sargu»] }\end{array}$ & {$[33,34]$} & Polyopisthocotylean & Not illustrated \\
\hline Microcotylidae & $\begin{array}{l}\text { Atriaster sp. (ex Diplodus } \\
\text { cervinus) }\end{array}$ & {$[37]$} & Polyopisthocotylean & $\begin{array}{l}\text { Includes spermiogenesis; } \\
\text { polygonal nucleus }\end{array}$ \\
\hline Microcotylidae & $\begin{array}{l}\text { Atriaster heterodus Lebedev \& } \\
\text { Parukhin, } 1969\end{array}$ & {$[96]$} & Polyopisthocotylean & $\begin{array}{l}\text { Includes spermiogenesis; } \\
\text { polygonal nucleus }\end{array}$ \\
\hline Microcotylidae & $\begin{array}{l}\text { Microcotyle sp. (ex Abudefduf } \\
\text { analogus) }\end{array}$ & {$[55]$} & Polyopisthocotylean & $\begin{array}{l}\text { Typical structure; membrane } \\
\text { ornamentation }\end{array}$ \\
\hline Microcotylidae & $\begin{array}{l}\text { Sciaenacotyle panceri (Sonsino, } \\
\text { 1891) Mamaev, } 1989 \text { [as } \\
\text { Microcotyle pancerii] }\end{array}$ & [89] & Polyopisthocotylean & Includes spermiogenesis \\
\hline Octomacridae & $\begin{array}{l}\text { Octomacrum lanceatum } \\
\text { Mueller, } 1934\end{array}$ & {$[28]$} & Polyopisthocotylean & $\begin{array}{l}\text { Includes spermiogenesis; typical } \\
\text { sections }\end{array}$ \\
\hline Plectanocotylidae & $\begin{array}{l}\text { Plectanocotyle gurnardi (Van } \\
\text { Beneden \& Hesse, 1863) }\end{array}$ & {$[105]$} & Polyopisthocotylean & $\begin{array}{l}\text { Only two micrographs, but } \\
\text { typical structure well visible }\end{array}$ \\
\hline Polystomatidae & $\begin{array}{l}\text { Neopolystoma spratti Pichelin, } \\
1995\end{array}$ & [109] & no & $\begin{array}{l}\text { Includes spermiogenesis; at level } \\
\text { of nucleus, the longitudinal } \\
\text { microtubules do not form a } \\
\text { complete circle }\end{array}$ \\
\hline Polystomatidae & $\begin{array}{l}\text { Pseudodiplorchis americanus } \\
\text { Rodgers \& Kuntz, 1940) } \\
\text { Yamaguti, } 1963\end{array}$ & {$[18]$} & no & $\begin{array}{l}\text { Includes spermiogenesis; sections } \\
\text { with nucleus have no lateral } \\
\text { microtubules }\end{array}$ \\
\hline Polystomatidae & Polystoma sp. & {$[68]$} & no & $\begin{array}{l}\text { Sections with nucleus have no } \\
\text { lateral microtubules }\end{array}$ \\
\hline Polystomatidae & Polystoma sp. & {$[11]$} & dubious & $\begin{array}{l}\text { Not illustrated; reports absence } \\
\text { of peripheral microtubules }\end{array}$ \\
\hline Polystomatidae & $\begin{array}{l}\text { Concinnocotyla australensis } \\
\text { (Reichenbach- Klinke, 1966) } \\
\text { Pichelin, } 1991\end{array}$ & {$[110]$} & Polyopisthocotylean & $\begin{array}{l}\text { Includes spermiogenesis; annular } \\
\text { nucleus section wrapping } \\
\text { axonemes; two lateral flanges }\end{array}$ \\
\hline Polystomatidae & Polystomoides sp. & {$[90,91]$} & dubious & $\begin{array}{l}\text { No section at the level of } \\
\text { nucleus }\end{array}$ \\
\hline Protomicrocotylidae & $\begin{array}{l}\text { Protomicrocotyle ivoriensis } \\
\text { Wahl, } 1972\end{array}$ & {$[99]$} & Polyopisthocotylean & Includes spermiogenesis \\
\hline Pterinotrematidae & Pterinotrema sp. & {$[34]$} & no & $\begin{array}{l}\text { Not illustrated; the text states } \\
\text { that lateral microtubules are } \\
\text { absent }\end{array}$ \\
\hline Pyragraphoridae & $\begin{array}{l}\text { Pyragraphorus pyragraphorus } \\
\text { (MacCallum \& MacCallum, } \\
\text { 1913) Sproston, } 1946\end{array}$ & {$[55]$} & Polyopisthocotylean & $\begin{array}{l}\text { Two micrographs; typical } \\
\text { structure }\end{array}$ \\
\hline Sphyranuridae & Sphyranura sp. & {$[34]$} & dubious & $\begin{array}{l}\text { Not illustrated; based on } \\
\text { "personal communication by } \\
\text { Oliver and Euzet" }\end{array}$ \\
\hline
\end{tabular}

\footnotetext{
* The systematic placement of species has been updated when appropriate; the host fish is indicated when the monogenean species was not identified.

** "Polyopisthocotylean": The Polyopisthocotylean structure is defined as two axonemes and a continuous row of peripheral microtubules in the region which contains the nucleus; "Aberrant": special case of Diplozoidae; "Dubious": available micrographs do not show the Polyopisthocotylean structure; "no": available micrographs show that the structure is not polyopisthocotylean.
} 

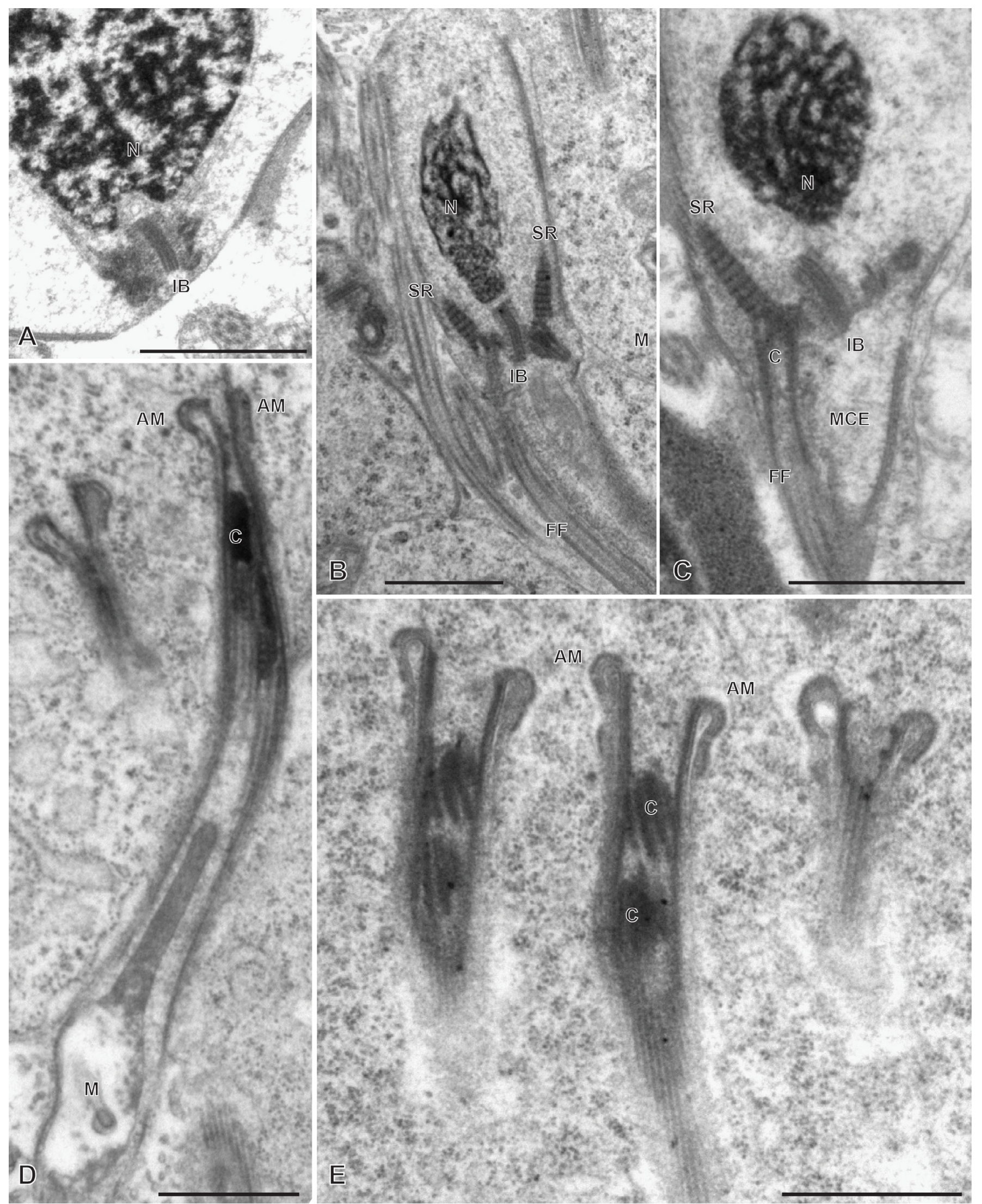

Figure 1. Early spermiogenesis in Chimaericola leptogaster. A, early zone of differentiation. Intercentriolar body next to cell membrane. B, C, fully developed zone of differentiation, longitudinal sections. Intercentriolar body flanked by two centrioles, each associated with a striated root. Two free flagella and one median cytoplasmic process are attached at the distal extremity of the zone of differentiation. D, E, longitudinal sections of late zones of differentiation, embedded in the cytoplasm of the mass of spermatids. Arching membranes at the proximal extremity of each zone of differentiation. Scale in all figures: $1 \mu \mathrm{m}$. 



Figure 2. Spermiogenesis in Chimaericola leptogaster (continued). A, transverse section of fully developed zone of differentiation, at the level of the two striated roots and the intercentriolar body. B, detail of intercentriolar body and peripheral microtubules. C, D, various oblique sections of intercentriolar body, centriole and striated roots. Scale in all figures: $500 \mathrm{~nm}$.

The mature zone of differentiation has the typical structure found in most neodermatans (Polyopisthocotylea, Digenea and Cestoda). It is conical, with arching membranes at its base (proximal extremity) and bears, at its distal extremity, two lateral free flagella and a median cytoplasmic process. The zone of differentiation contains two centrioles flanking the intercentriolar body and a longitudinal striated root is associated with each centriole (Figures 1B, 1C, 2). The mitochondrion and the nucleus pass through the zone of differentiation (Figures 1B, 1C, 2) into the median cytoplasmic process (Figure 1B). The two flagella fuse with the median cytoplasmic process; the late zone of differentiation contains the two centrioles, slightly slanted (Figure 1E) and has arching membranes at its proximal extremity (Figure 1D, 1E).

\section{Spermatozoon of the chimaericolid Chimaericola leptogaster (Figures 3 and 4)}

The mature spermatozoon is a very elongate and thin cell; the anteroposterior sequence of transverse sections was deduced from comparison of sections, based on the simple principle that the nucleus is posterior and the centrioles are anterior, as in all neodermatans [35,39]. The axonemes show a typical trepaxonematan $9+$ " 1 " structure (Figure 3E-W, transverse sections; Figure 3X, longitudinal section).

The general structure of the spermatozoon is biflagellate, with two axonemes incorporated into the sperm body, a longitudinal mitochondrion, a nucleus, and cortical longitudinal microtubules. The anterior region of the spermatozoon is pointed; it shows a few peripheral 


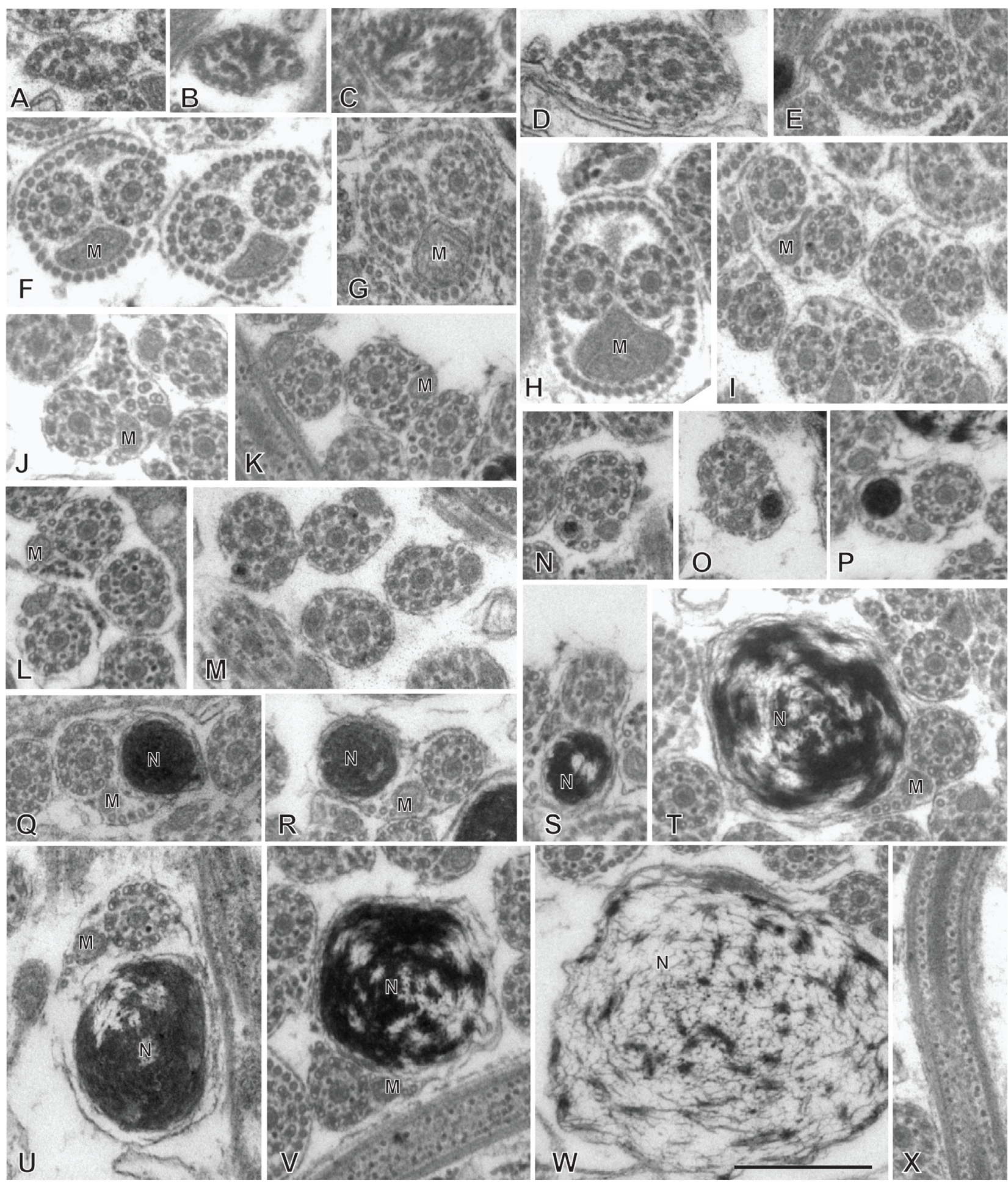

Figure 3. Spermatozoon of Chimaericola leptogaster. A-W, transverse sections, in antero-posterior sequence; X, longitudinal section. A-C, anteriormost part of spermatozoon; peripheral microtubules and progressive appearance of the two centrioles. D, E, one fully formed axoneme and section of the centriole of the other axoneme. F-H, peripheral microtubules (full ring in $\mathrm{G}, \mathrm{H}$ ), two axonemes, and mitochondrion. I, two axonemes, peripheral row of microtubules reduced to a few units, and mitochondrion. J, one axoneme, distal extremity of other axoneme as scattered doublets and central core, a few remaining peripheral microtubules, and mitochondrion. K-M, one axoneme and mitochondrion, a few peripheral microtubules. N-P, one axoneme, a few peripheral microtubules, mitochondrion and section of the anterior thin part of the nucleus, which is wider as sections are more posterior. Q-S, one axoneme, a few peripheral microtubules, mitochondrion, and section of nucleus approximately as wide as axoneme. T-W, one axoneme, a few peripheral microtubules, mitochondrion, and wide section of nucleus. $\mathrm{W}$ is a very wide section with electron-transparent chromatin. $\mathrm{X}$, typical trepaxonematan axoneme. Scale in W, valid for all figures: $500 \mathrm{~nm}$. 


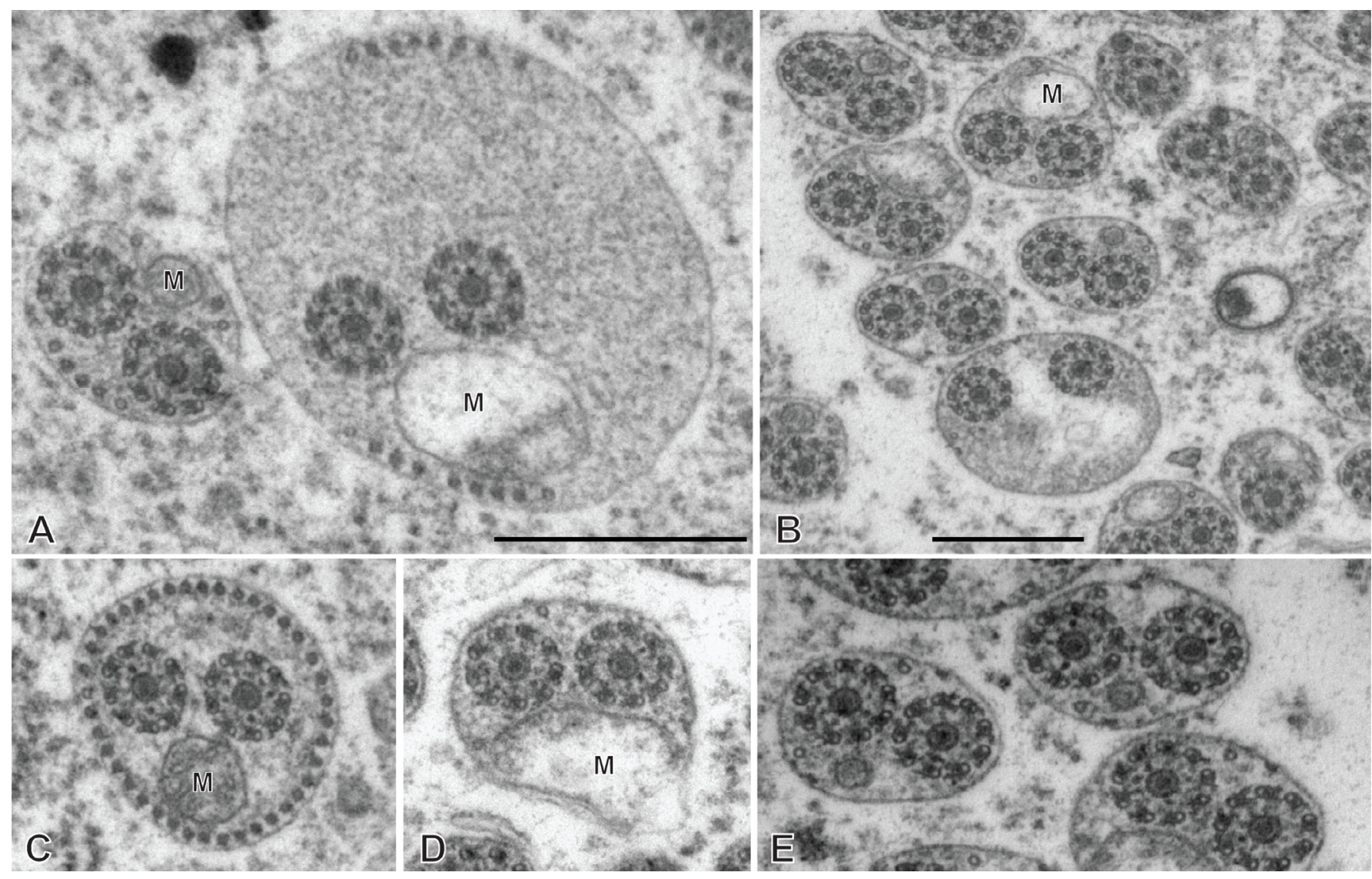

Figure 4. Altered spermatozoa of Chimaericola leptogaster in caeca and genito-intestinal canal. A, B, transverse sections of altered

microtubules and the centriolar derivative of one of the axonemes (Figure 3A-B). More posteriorly, sections show the second centriolar derivative (Figure $3 \mathrm{C}$ ) and the first axoneme, surrounded by a continuous row of peripheral microtubules (Figure 3D-E). The next region, in an antero-posterior sequence, contains the two axonemes, the peripheral row of microtubules and a section of the mitochondrion (Figure 3F-H). The following region has only a few peripheral microtubules (Figure 3I-M); one of the axonemes finishes (as doublets, Figure 3J) and thus the rest of the cell contains a single axoneme. The anteriormost sections in this region show only the mitochondrion, which has a small diameter in cross sections, but more posterior sections show the first sections of the nucleus which are sections with very small diameter (Figure 3N-P). The posterior region of the spermatozoon contains a single axoneme, a few peripheral microtubules, a small diameter section of the mitochondrion, and a section of the nucleus with a diameter increasing towards the posterior end (Figure 3Q-W). The chromatin of the nucleus is compact and electron-dense in its thin, anterior part (Figure $3 \mathrm{~N}-\mathrm{Q}$ ) then partly compact and partly fibrous (Figure 3R-V), and finally fibrous and electron-lucent in its posteriormost part (Figure $3 \mathrm{~W}$ ). The distal posterior extremity of the spermatozoon contains only the nucleus and a single axoneme (Figure $3 \mathrm{~W}$ ).
Figure 13 is a schematic drawing of our interpretation of the structure of the mature spermatozoon of Chimaericola leptogaster.

While useful information about sperm structure should be sought only from sections of spermatozoa in the reproductive organs, we had the opportunity to observe sections in the caeca and in the genito-intestinal canal. Sections were generally indicative of cells in hypotonic media, with swollen cytoplasm with uniform contents and swollen mitochondria (Figure 4A, B, D, E). Occasionally, a few sections which seemed normal (Figure 4C, compare with Figure 3G) were found, and probably correspond to spermatozoa which were recently transferred to these organs.

\section{Spermiogenesis in the hexabothriid Rajonchocotyle emarginata (Figures 5-7)}

Spermiogenesis involves the formation of a zone of differentiation. The early zone of differentiation is visible as a small protuberance with subpellicular microtubules (Figure 5A, D); at this stage, the nucleus is round and the mitochondria are gathered above the nucleus. Slightly more advanced zones of differentiation show the formation of the intercentriolar body and two centrioles, close to the cell membrane (Figure 5C, D). The two centrioles give rise 

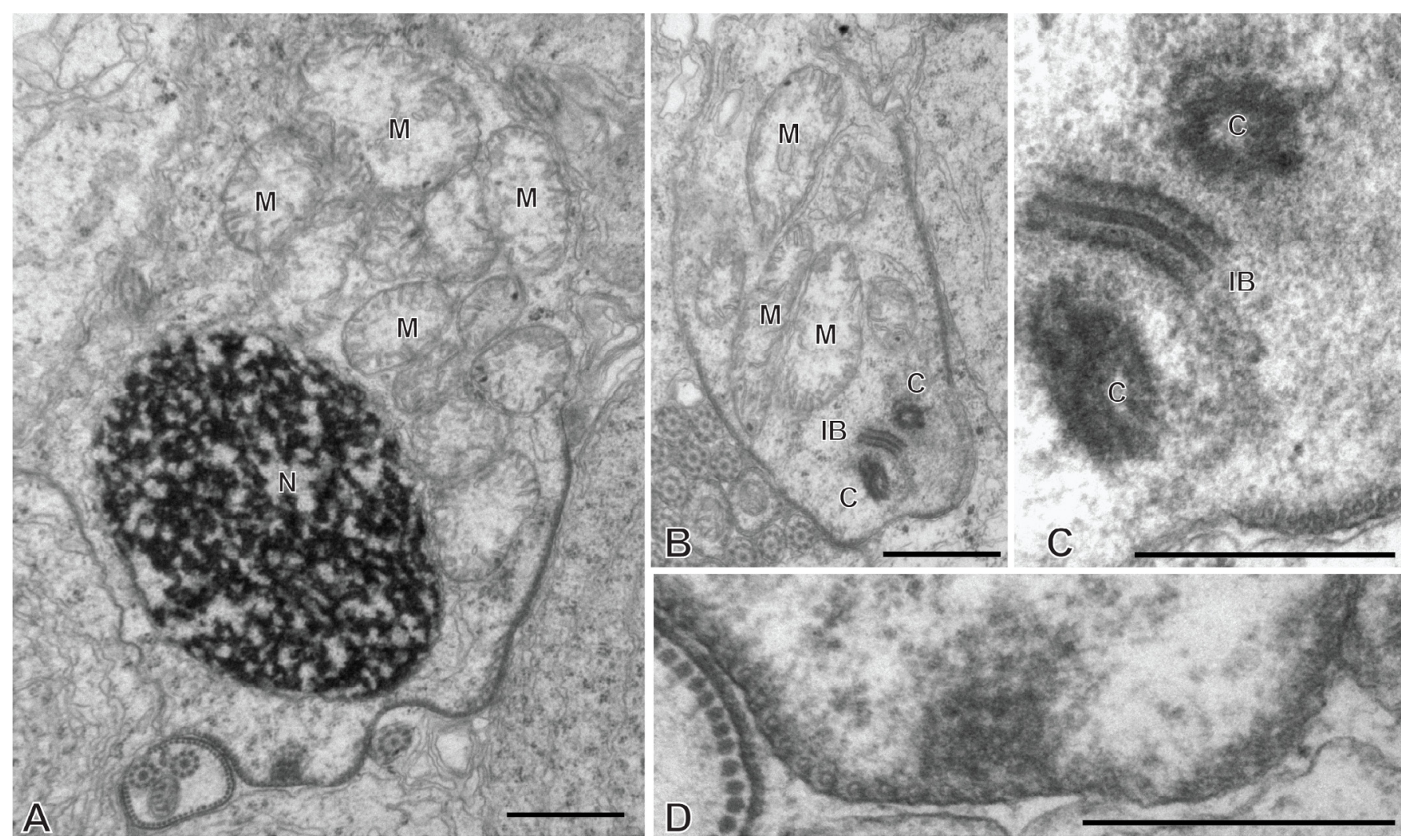

Figure 5. Early spermiogenesis in Rajonchocotyle emarginata. A, B, very early spermatid with round nucleus and mitochondria gathered above nucleus. The early zone of differentiation is lined with microtubules; constituents of the zone of differentiation visible as a densification of the cytoplasm. C, early zone of differentiation, with fully formed intercentriolar body and two centrioles. This section does not cut the nucleus. D, magnification of early zone of differentiation in A. Scales in all figures: $500 \mathrm{~nm}$.

to two free flagella which are first in an inversed position, with their distal extremities directed toward the basal part of the spermatid (Figure 6A). The next stage is a typical, conical, zone of differentiation, which contains peripheral microtubules, the elongating nucleus with lamellated chromatin, roundish mitochondria, and two centrioles each associated with a striated root and located on each side of the intercentriolar body. The distal extremity of the zone of differentiation bears three almost parallel processes, the two lateral free flagella, and the median cytoplasmic process (Figure 6B-I). The mitochondria seem to be separate, as roundish discrete elements, in the zone of differentiation (Figure 6D, E, G-I) but are fused into a single ribbon in the median cytoplasmic process (Figure 7). The median cytoplasmic process contains the mitochondrial ribbon and two sets of peripheral microtubules, one ventral and one dorsal (Figure 7B-G). Electron-dense zones of the membrane, known as "attachment zones" are visible on each side of the median cytoplasmic process (two on each side), where no peripheral microtubules are present (Figure 7B). The free flagella show the typical trepaxonematan $9+$ " 1 " structure (Figure 7B-H) but their distal extremities lack the central core, thus producing distal sections with $9+0$ structure (Figure 7I). The free flagella fuse with the median cytoplasmic process on its lateral sides; one flagellum fuses before the other, thus producing sections with a single axoneme incorporated into the median cytoplasmic process (Figure $7 \mathrm{H}$ ). The advanced zone of differentiation is elongate and deeply embedded in a canal into the cytoplasm of the spermatid mass (Figure 8). Arching membranes are visible at the anterior (proximal) part (Figure 8A-D), and the transverse section of the canal shows that it is often surrounded by additional membranes (Figure 8G, 8I). At this stage, transverse sections of the zone of differentiation show a very characteristic structure, with two axonemes, a section of mitochondrion and an almost complete peripheral row of parallel longitudinal microtubules (Figure 8E-I). A particularity at this stage is the presence of ornamentation external to the membrane along the periphery, except where microtubules are absent (Figure 8E-I).

\section{Spermatozoon of the hexabothriid Rajonchocotyle emarginata (Figures 9 and 10)}

The mature spermatozoon is a very elongate and thin cell (Figures 9 and 10), with, according to our reconstitution of the anteroposterior sequence of transverse sections, a wider posterior extremity containing the nucleus 

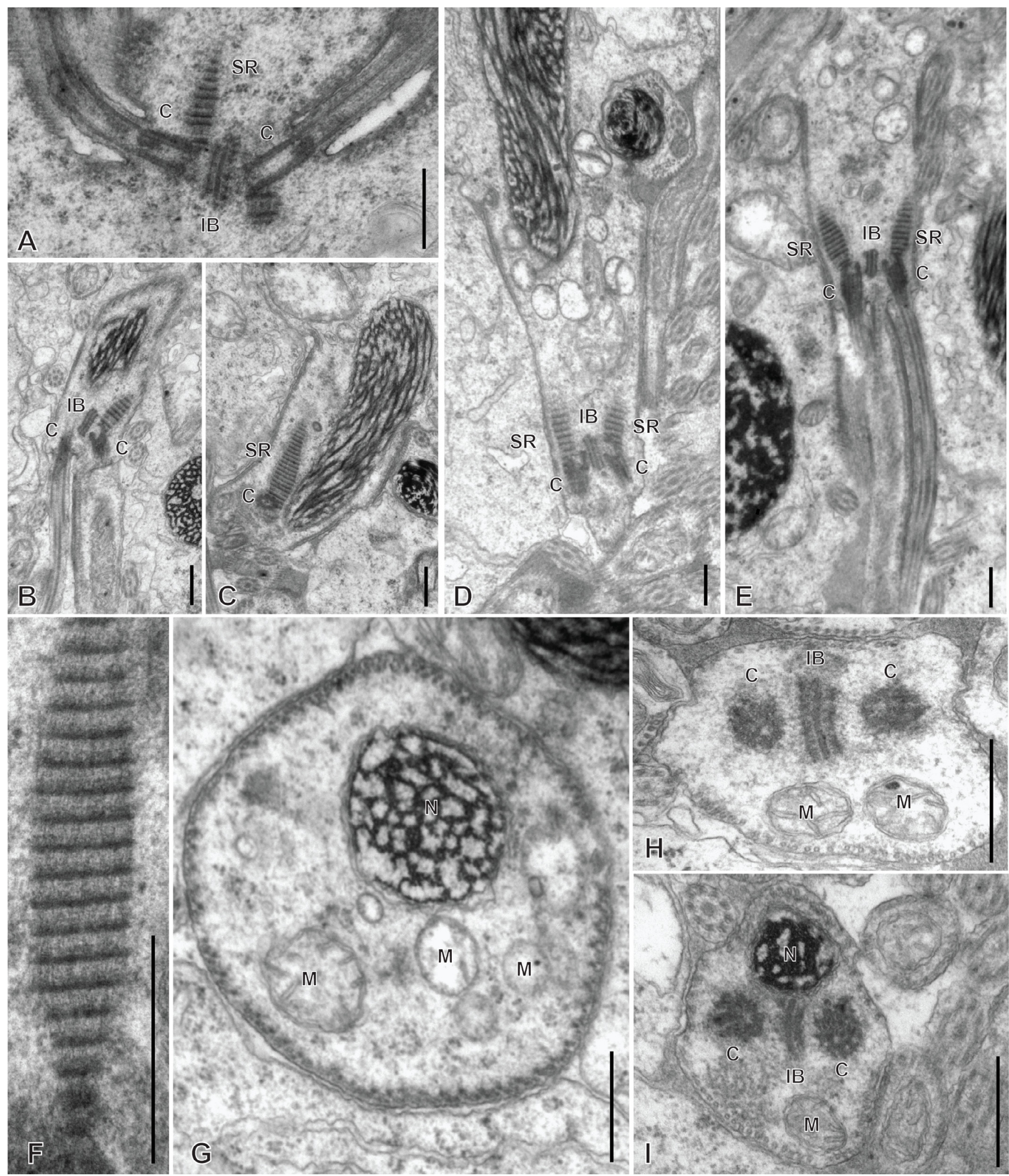

Figure 6. Spermiogenesis in Rajonchocotyle emarginata, fully formed zones of differentiation. A, zone of differentiation at stage when free flagella are directed backwards along the zone of differentiation. B-E, longitudinal sections of fully formed zones of differentiation, showing typical morphology with elongate nucleus with lamellated chromatin, two centrioles, two striated roots, two free flagella and median cytoplasmic process. Mitochondria appear separate and roundish. F, high magnification of striated root, longitudinal section. G-H, transverse sections of fully formed zones of differentiation; row of peripheral microtubules in all sections. G, section in proximal part of zone of differentiation, showing nucleus and several mitochondria. H, I, sections at level of intercentriolar body and centrioles, with nucleus and/or mitochondria. Scales in all figures: $500 \mathrm{~nm}$. 

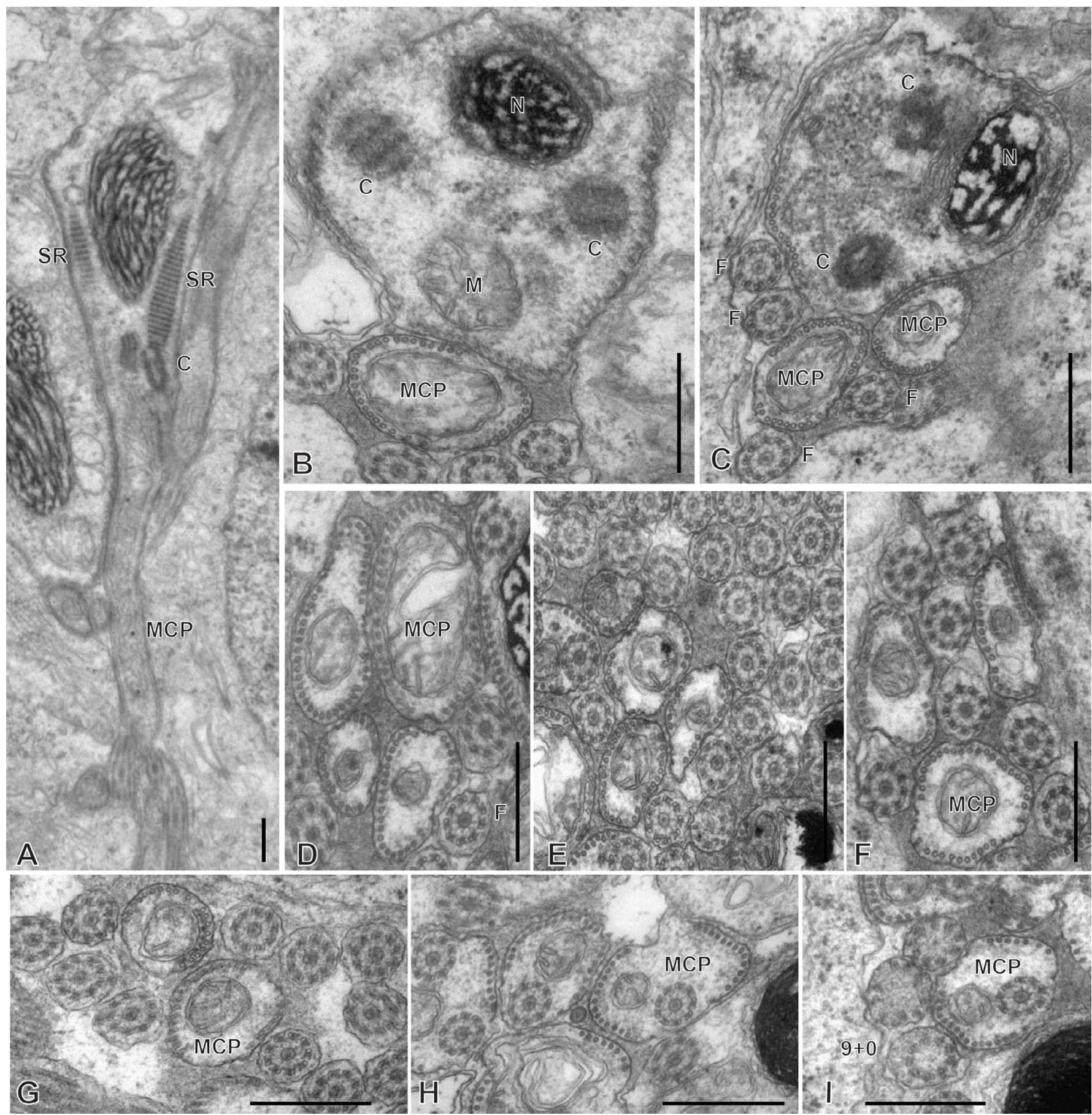

Figure 7. Spermiogenesis in Rajonchocotyle emarginata, fully formed zones of differentiation and median cytoplasmic process. A, longitudinal section of fully formed zone of differentiation showing long median cytoplasmic process at its distal extremity. B, C, side-byside sections in zone of differentiation, with nucleus and/or mitochondrion, and median cytoplasmic process, with section of elongating mitochondrion; free flagella, with $9+$ " 1 " trepaxonematan structure, are located along the median cytoplasmic process and parallel to it. $\mathrm{D}-\mathrm{G}$, sections of median cytoplasmic process with various numbers of peripheral microtubules. H, median cytoplasmic process with only one axoneme incorporated. I, transverse section of distal extremity of free flagella showing $9+0$ structure. Scales in all figures: $500 \mathrm{~nm}$.

(Figure 10). The axonemes show a typical trepaxonema$\tan 9+$ "1" structure (Figures 9 and 10, transverse sections; Figure 9H, longitudinal section).

The general structure of the spermatozoon is biflagellate, with two axonemes incorporated into the sperm body, a longitudinal mitochondrion, a nucleus, and peripheral longitudinal microtubules. The anterior extremity of the spermatozoon is thinner than the rest; it contains a single axoneme and peripheral microtubules (Figure 9A,B). The anterior region is identical to the elongate late zone of differentiation shown in Figure 8, with a circular section, an almost continuous circle of 

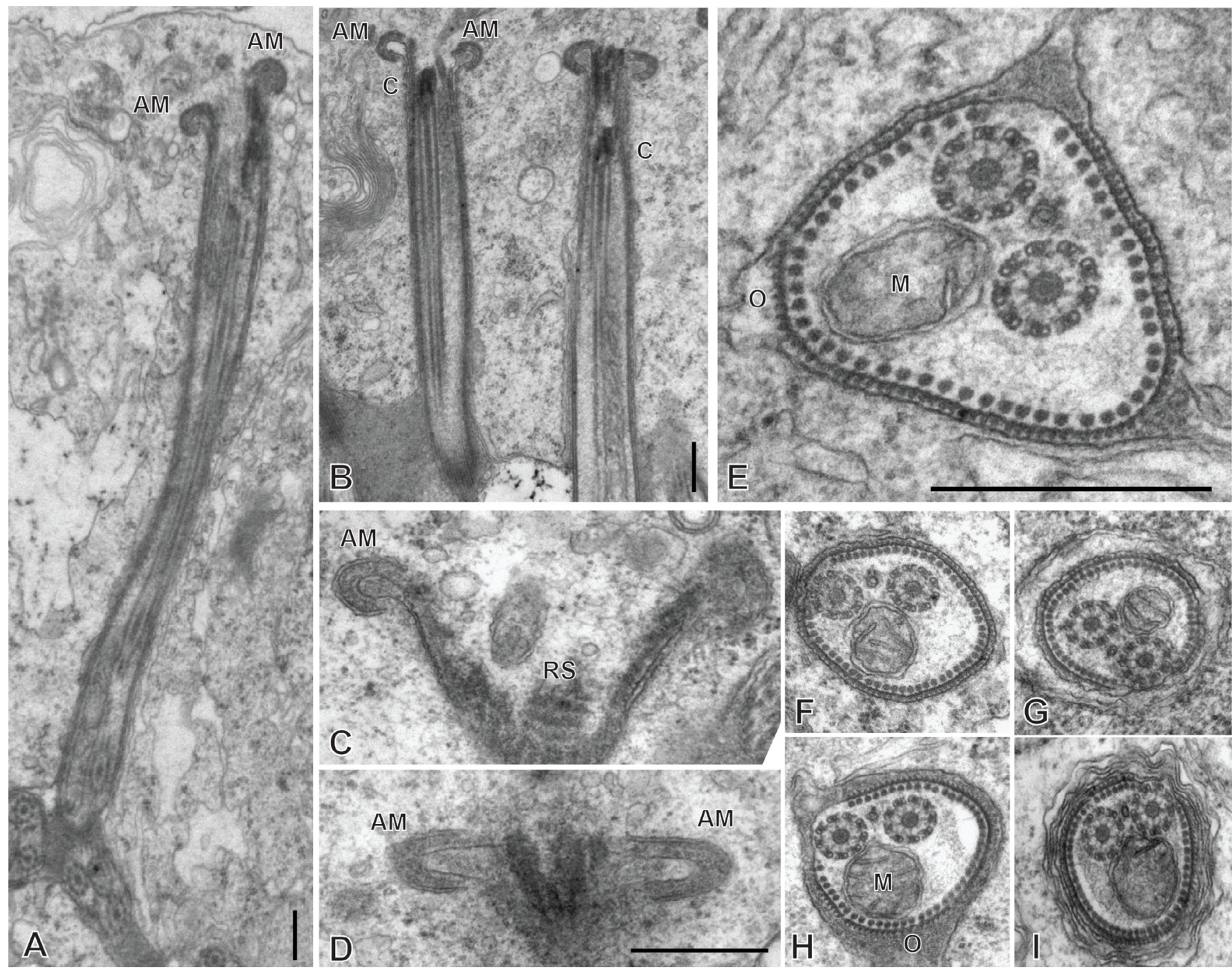

Figure 8. Spermiogenesis in Rajonchocotyle emarginata, late zones of differentiation. A, B, longitudinal sections of late zones of differentiation embedded in the cytoplasm of the mass of spermatids. Arching membranes at the anterior (proximal) extremity. C, D, high magnification of arching membranes. E, high magnification of transverse section of late zone of differentiation. Two fullyincorporated axonemes, one section of mitochondrion, and almost complete row of peripheral longitudinal microtubules. Note dense material external to cell membrane, or "ornamentation". F-I, various transverse sections of late zones of differentiation; the cytoplasm of the surrounding spermatid is often lined with membranes (several layers in I). Scale in D valid for C- I. Scales in all figures: $500 \mathrm{~nm}$.

longitudinal parallel microtubules associated with characteristic external ornamentation on the membrane, two axonemes and a section of the mitochondrial ribbon (Figure 9C-G); longitudinal sections show that the mitochondrion is a regular ribbon and that the external ornamentation looks like a continuous fuzzy layer (Figure 9H). A section of the nucleus with very small diameter, reduced to the nuclear envelope without electron-dense chromatin, is seen in all sections except the anteriormost ones (Figure 9C-Q). More posteriorly, the external ornamentation progressively disappears and the continuous row of peripheral microtubules is gradually replaced by two sets of microtubules without ornamentation, one dorsal and one ventral; attachment zones are visible, thus indicating that this region originates from the fusion of the free flagella with the median cytoplasmic process (Figure 9I, 9L-Q). A part of this region has very few microtubules and sections are more oval than triangular in shape (Figure 9O-Q). The posterior region of the spermatozoon contains the same elements (two axonemes, peripheral microtubules and a section of the ribbon-shaped mitochondrion) but the section of the nucleus represents an increasing portion of the section (Figure 9R, 10A-D). At its wider part, the nucleus has additional membranes around the nuclear envelope and fibrous chromatin. The posterior part of the spermatozoon shows the same structure but only one axoneme is present (Figure 10E-G). The posterior extremity contains a section of the nucleus with small diameter and only a few microtubules (Figure 10H, I). 

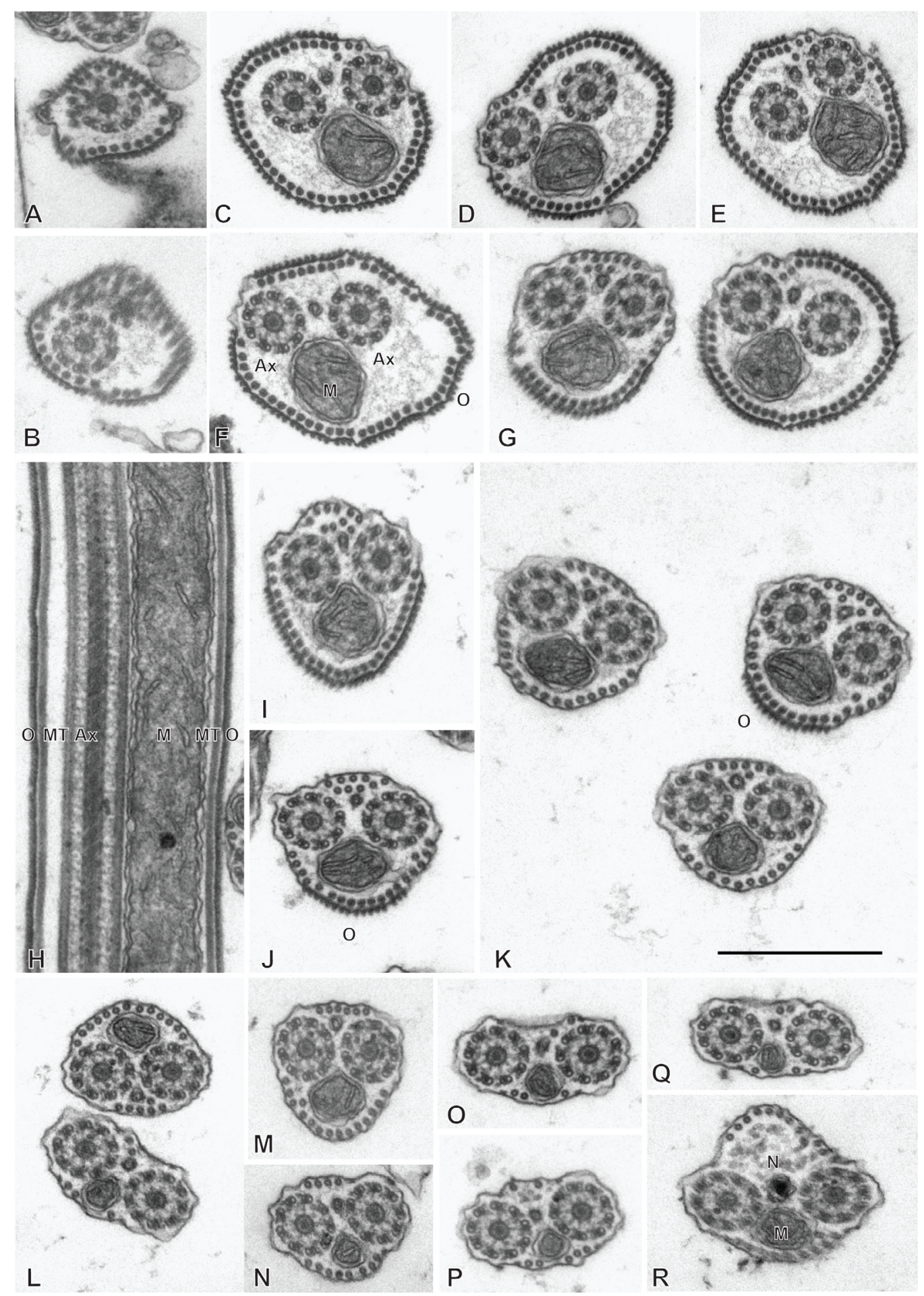

Figure 9. Spermatozoon of Rajonchocotyle emarginata, anterior part. A-G and I-R, transverse sections, in antero-posterior sequence; $\mathrm{H}$, longitudinal section. A, B, anteriormost part of spermatozoon: one axoneme, one centriolar derivative, peripheral row of microtubules and ornamentation on membrane. C-G, region of spermatozoon with membrane ornamentation. Microtubules generally as a single row of peripheral parallel units, two axonemes and section of mitochondrion. G shows together a typical section (right) and an intermediary section (left) with ornamentation only on ventral side of spermatozoon. H, longitudinal section in region with membrane ornamentation, showing axoneme with typical trepaxonematan $9+$ " 1 " structure, mitochondrion with very regular diameter, peripheral microtubules and external ornamentation on cell membrane (microtubules and ornamentation visible on both sides). I-K, various sections at the limit of region with ornamentation and region without ornamentation and additional microtubules. A section of mitochondrion is visible in all sections; a section of nucleus appears, with very small diameter. L-R, sections in the region posterior to membrane ornamentation, showing decreasing number of external microtubules and progressive appearance of section of nucleus. Scale in K, valid for all figures: $500 \mathrm{~nm}$. 


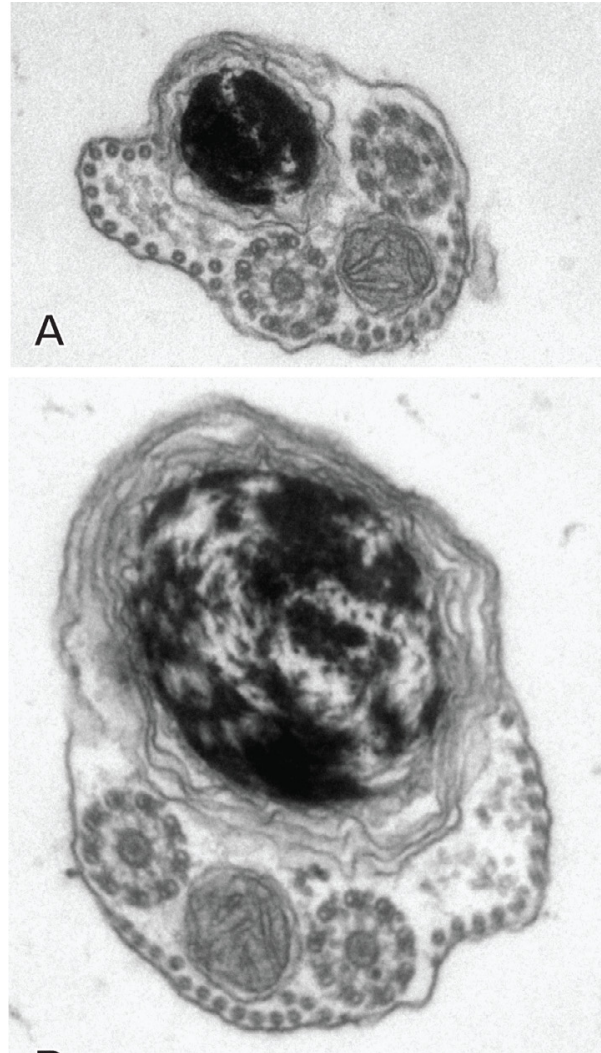

B
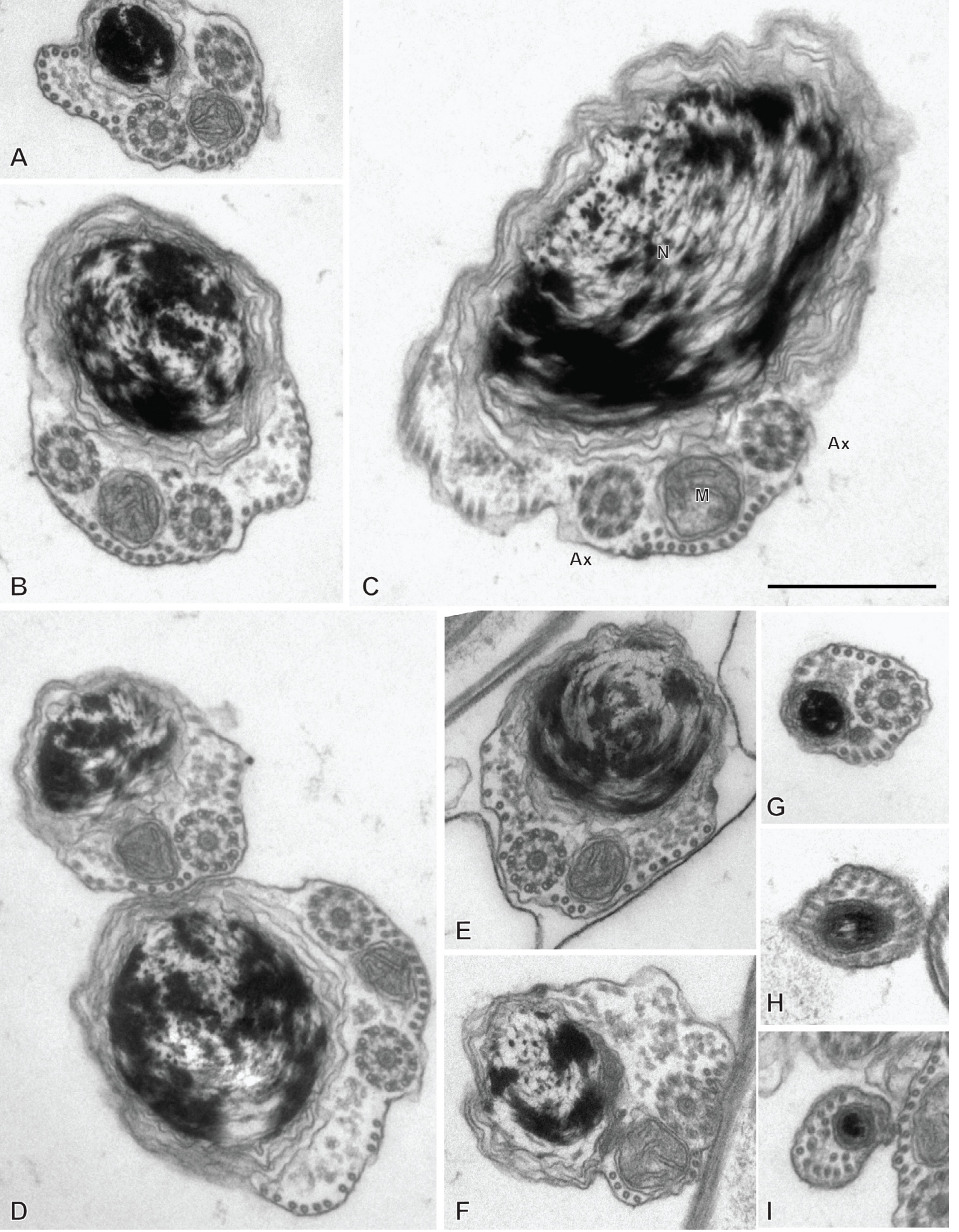

Figure 10. Spermatozoon of Rajonchocotyle emarginata, posterior part. A-I, transverse sections, in antero- posterior sequence. A-C, section with two axonemes, mitochondrion, nucleus with various degrees of dilatation, and peripheral microtubules. The nuclear envelope often has additional membranes. D-F, sections with a single axoneme, mitochondrion, nucleus, and peripheral microtubules. $\mathrm{G}$, single axoneme, section of nucleus with dense chromatin and small diameter, mitochondrion with very small diameter, and peripheral microtubules. H, I, extremity with section of nucleus and no mitochondrion. A few microtubules present. Scale in C, valid for all figures: $500 \mathrm{~nm}$. 
Figure 14 is a schematic drawing of our interpretation of the structure of the mature spermatozoon of Rajonchocotyle emarginata.

\section{Spermatozoon of the hexabothriid Callorhynchocotyle callorhynchi (Figures 11 and 12)}

Spermiogenesis was not observed in this species. The mature spermatozoon is a very elongate and thin cell (Figures 11 and 12), with, according to our reconstitution of the anteroposterior sequence of transverse sections, a larger posterior extremity containing the nucleus and a particular region containing what looks like an undulating membrane. The axonemes show a typical trepaxonematan $9+$ "1" structure (Figures 11 and 12).

The general structure of the spermatozoon is biflagellate, with two axonemes incorporated into the sperm body, a longitudinal mitochondrion, a nucleus, and peripheral longitudinal microtubules. The anterior extremity of the spermatozoon is thin; it contains only a few microtubules (Figure 11A-C). More posteriorly, the first axoneme appears (Figure 11D, E) followed by the second axoneme (Figure 11G). At the level of the first centriole and slightly posterior to it, two dense zones are visible within the cytoplasm, outside the microtubule row (Figure 11C-F). The anterior region of the spermatozoon contains the two axonemes and numerous microtubules, organized at two rows of dorsal and ventral microtubules, each doubled by a more internal row of microtubules (Figure $11 \mathrm{H}-\mathrm{K}$ ); no cortical microtubules are present on the sides. This region does not contain a section of the mitochondrion nor of the nucleus. Progressively, this region is transformed in a region with two sets of microtubules, one ventral and one dorsal, devoid of the internal row of microtubules; a section of the mitochondrion and a section of the nucleus appear (Figure 11L-P); intermediary sections (Figure 11L-P) show that the second, internal row of microtubules is progressively lost. The next region has only the "typical" elements of a mature neodermatan spermatozoon, i.e. two lateral axonemes, a mitochondrion, a nucleus, and two rows of peripheral microtubules, one on the ventral and one on the dorsal side (Figure 11Q-T). More posteriorly, one of the axonemes disappears and sections contain only a single axoneme, a section of mitochondrion and nucleus, and dorsal and ventral peripheral microtubules; the nucleus has a wide section with fibrous chromatin (Figure 12 A-C). The next region is quite particular: the shape of transverse sections progressively flattens, with the axoneme on one side, the section of the nucleus on the other side, and a thin layer of cytoplasm containing only the two rows of peripheral microtubules, now close one to the other, between the axoneme and the nucleus (Figure 12D-I). Most posterior sections show the axoneme ending as singlets (Figure 12K,L). The posterior extremity shows only a comma-shape section with peripheral microtubules (Figure $12 \mathrm{M}-\mathrm{O}$ ), then a small structure with only a few microtubules (Figure 12P).
Figure 15 is a schematic drawing of our interpretation of the structure of the mature spermatozoon of Callorhynchocotyle callorhynchi.

\section{Discussion}

\section{Significance of variations of sperm ultrastructure within the Polyopisthocotylea}

The ultrastructure of spermatozoa has been considered as relatively homogeneous among polyopisthocotyleans $[35,46]$, and sperm structure did not provide any character useful for understanding the relationships between the various families of polyopisthocotylean monogeneans $[34,42]$. This is a contrasting situation to what was found in the monopisthocotyleans, in which the structure is highly variable $[16,17,24,39,44,46,49-53,57,59-63,65,66,71,72,76$, 77,93,98,101-103,106-108] and makes it possible to distinguish synapomorphies for certain families or groups of families [34,35,38,39,42,43,46,57,61,66].

In most polyopisthocotylean monogeneans, the principal region of the spermatozoon (i.e. the region with the nucleus and mitochondrion) has two axonemes and a continuous row of peripheral microtubules. A single significant divergence from this pattern was found in the Diplozoidae $[47,48]$. Diplozoids are unique in the monogeneans (and even in the animal world) in that the two hermaphrodite members of a pair are united for life, with the genital ducts in permanent communication [15]. Sperm morphology is known to be driven by constraints of sperm function and competition [25]; it was hypothesized $[39,47]$ that the aberrant sperm structure in diplozoids was the result of the absence of sperm competition, and thus more representative of a variation of fertilization biology than the mark of a distinctive diplozoid branch in the polyopisthocotylean tree. A parallel situation is also encountered in the schistosomes (Digenea) [31,36,39,45].

A special structure found in rare polyopisthocotyleans is an undulating membrane. A typical undulating membrane was described in Gotocotyla sp. [56]. This undulating membrane is composed of a lateral flange containing more than one hundred parallel microtubules, and observations of living spermatozoa showed that the undulating membrane was functional, i.e. showing active motility [56]. This was considered an autapomorphy of Gotocotyla [34]. Other structures superficially looking like this undulating membrane have been mentioned in various polyopisthocotyleans, generally in the form of a lateral flange with longitudinal peripheral microtubules. Examples, listed by Quilichini et al. [89] are Pricea multae, Discocotyle sagittata and Concinnocotyla australensis (references in Table 1); none of these are similar to what exists in Gotocotyla, and none have been shown to be functional. A single flange is found in P. multae and $D$. sagittata, but there are two flanges in C. australensis. We have no evidence that these various lateral flanges are homologous between themselves, and they should probably be considered as autapomorphies of the various taxa in 


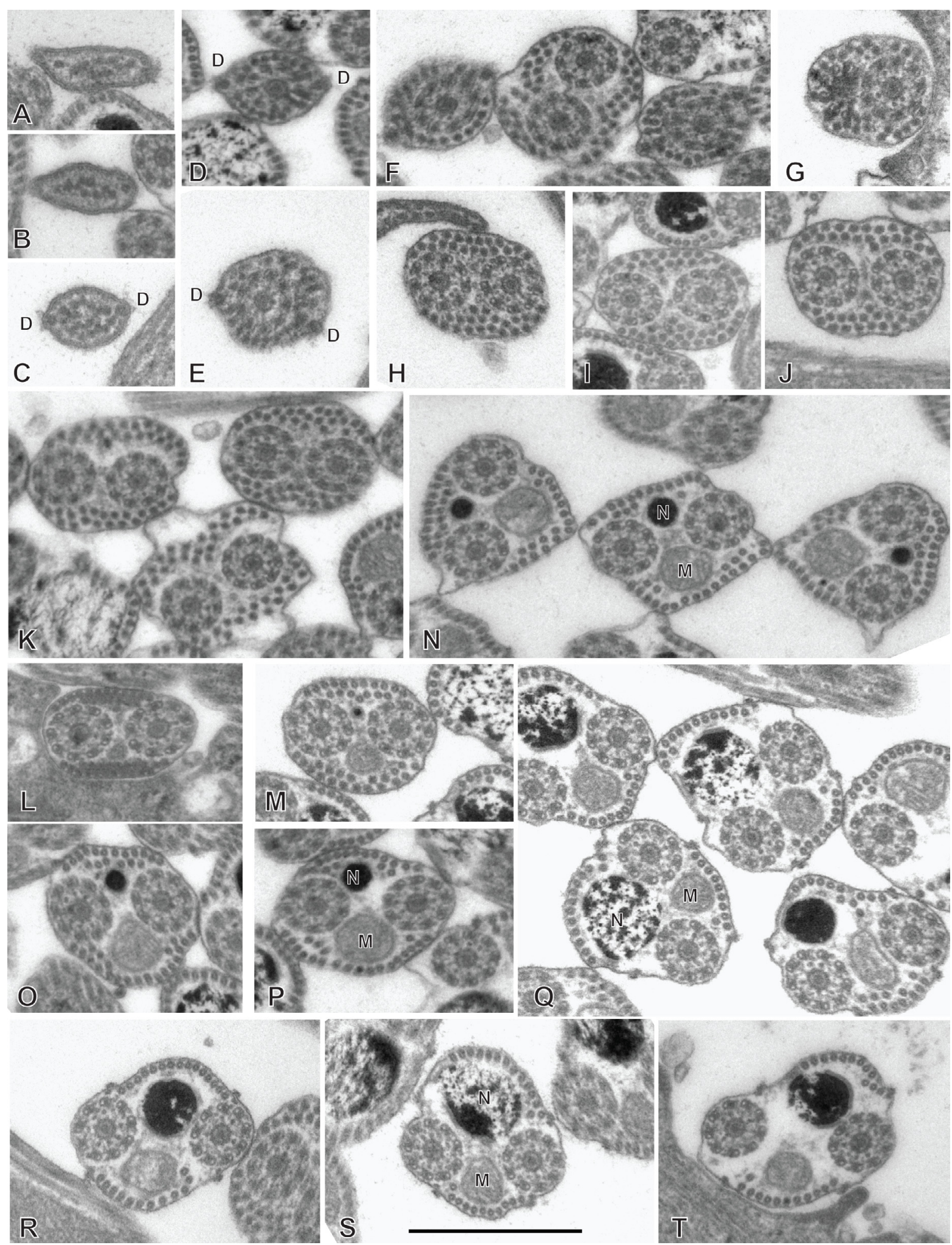

Figure 11. Spermatozoon of Callorhynchocotyle callorhynchi, anterior part. A-T, transverse sections, in antero-posterior sequence. A-C, anteriormost sections, showing a few microtubules. D, E, centriole and first axoneme. F, two sections with single axoneme surrounding a section with two axonemes. G, one fully formed axoneme and centriole of other axoneme. H-L, sections with two axonemes, peripheral microtubules on dorsal and ventral part, and additional microtubules. M-P, sections with peripheral microtubules on dorsal and ventral part, progressive disappearance of additional microtubules, appearance of sections of mitochondrion and nucleus. Q-T, "typical" sections of spermatozoon, showing two axonemes, one section of mitochondrion, one section of nucleus, ventral and dorsal peripheral microtubules and a few scattered additional microtubules. Scale in S, valid for all figures: $500 \mathrm{~nm}$. 

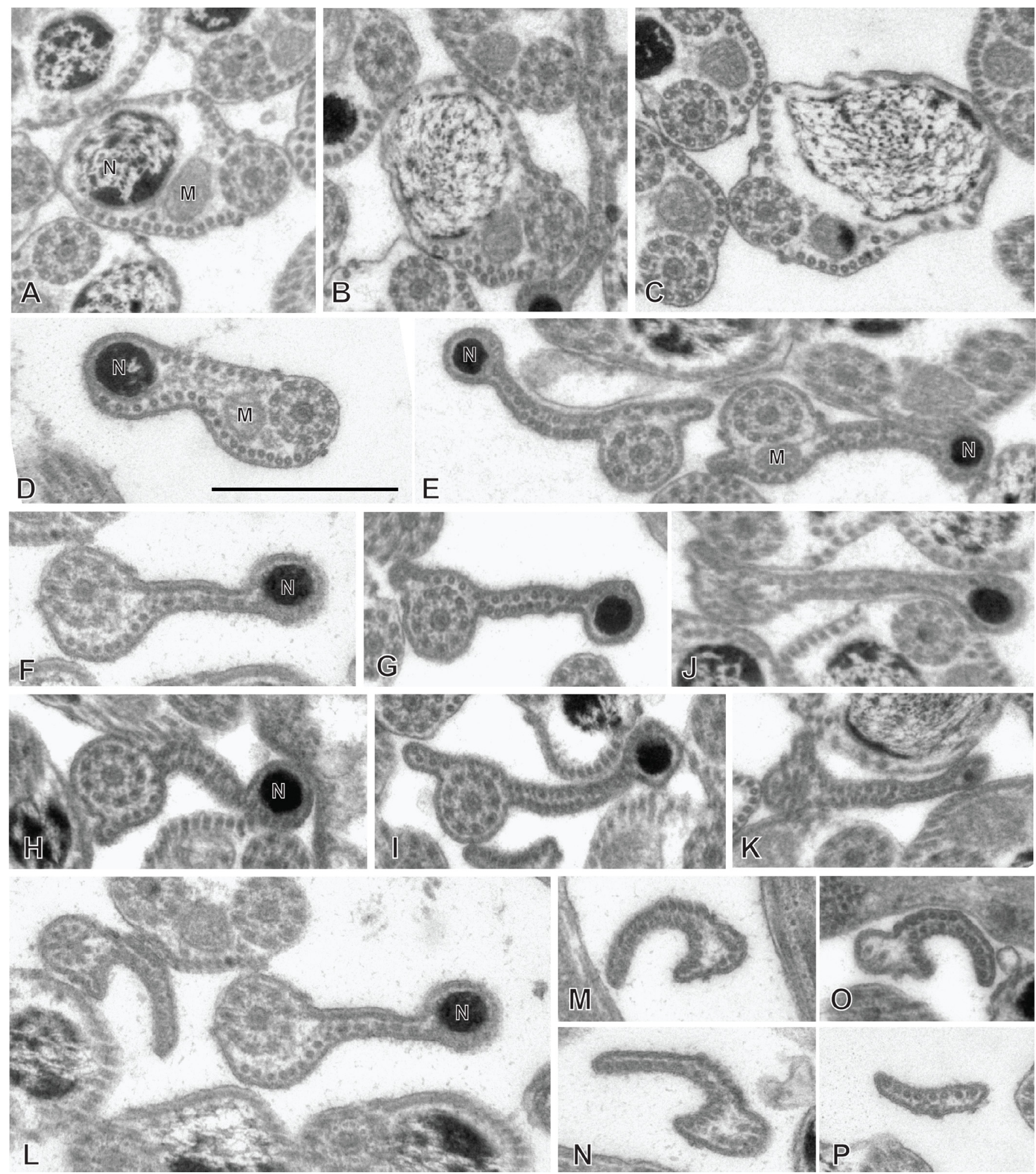

Figure 12. Spermatozoon of Callorhynchocotyle callorhynchi, posterior part. A-P, transverse sections, in antero-posterior sequence. A-C, similar to "typical" sections of spermatozoon, with one section of mitochondrion, one section of nucleus, ventral and dorsal peripheral microtubules and a few scattered additional microtubules, but with a single axoneme. The nucleus chromatin is not electron-dense. D, intermediary region in which the section is not flattened in the middle; one axoneme, ventral and dorsal peripheral microtubules, section of mitochondrion with very small diameter, and section of nucleus with electron-dense content. E-I, various sections in the flattened region, with single axoneme, ventral and dorsal peripheral microtubules, no mitochondrion, nucleus as small diameter electron-dense section. J-K, flattened region, distal extremity of axoneme; the section of the nucleus has a very small diameter or almost disappeared $(\mathrm{K})$. L, side-by-side section in flattened region and distal comma-shaped section with axoneme reduced to a circle of single microtubules. M-O, distal comma-shaped section, no axoneme. P, distalmost section. Scale in E, valid for all figures: 500 nm. 


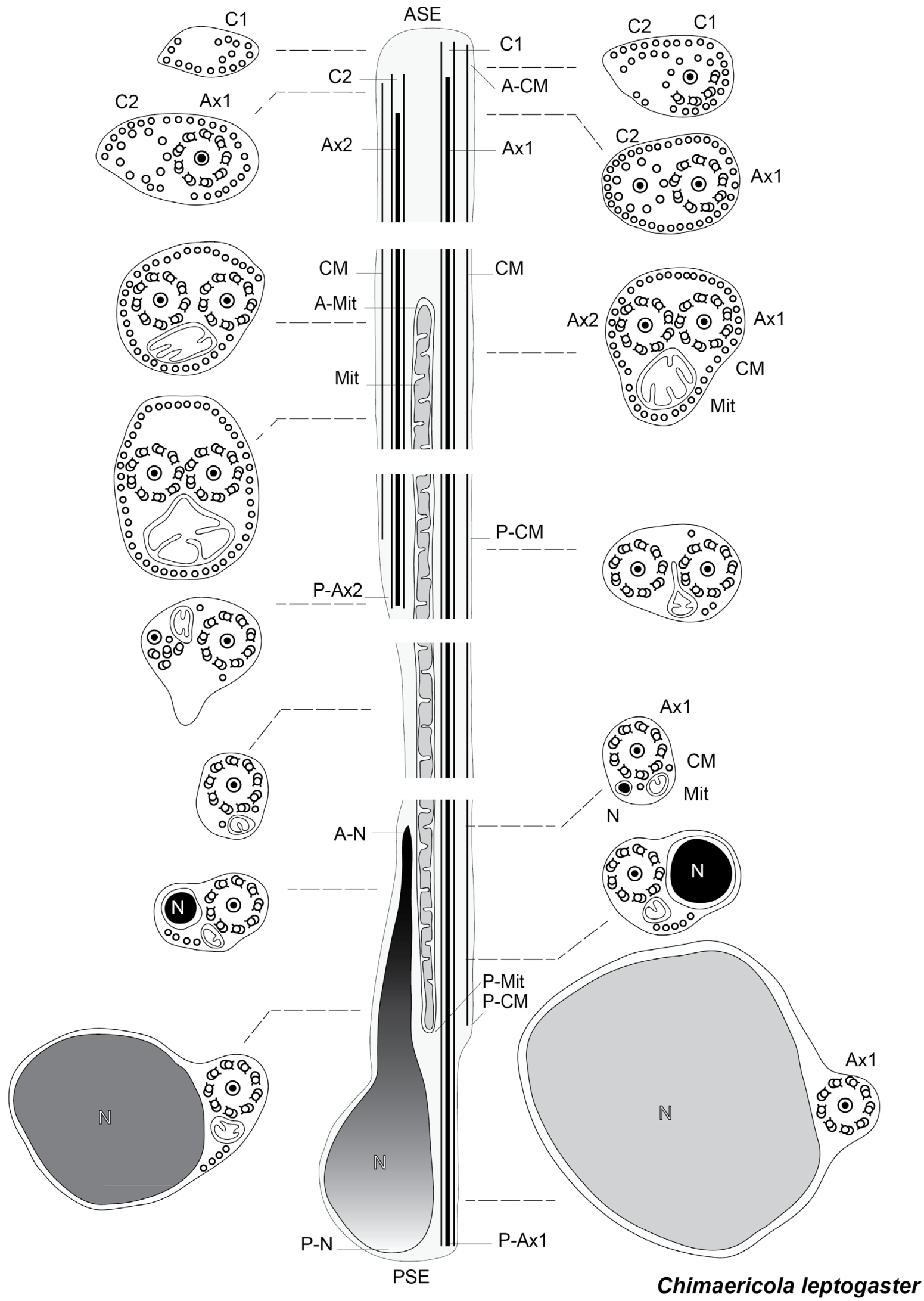

Figure 13. Schematic reconstruction of the spermatozoon of Chimaericola leptogaster. 


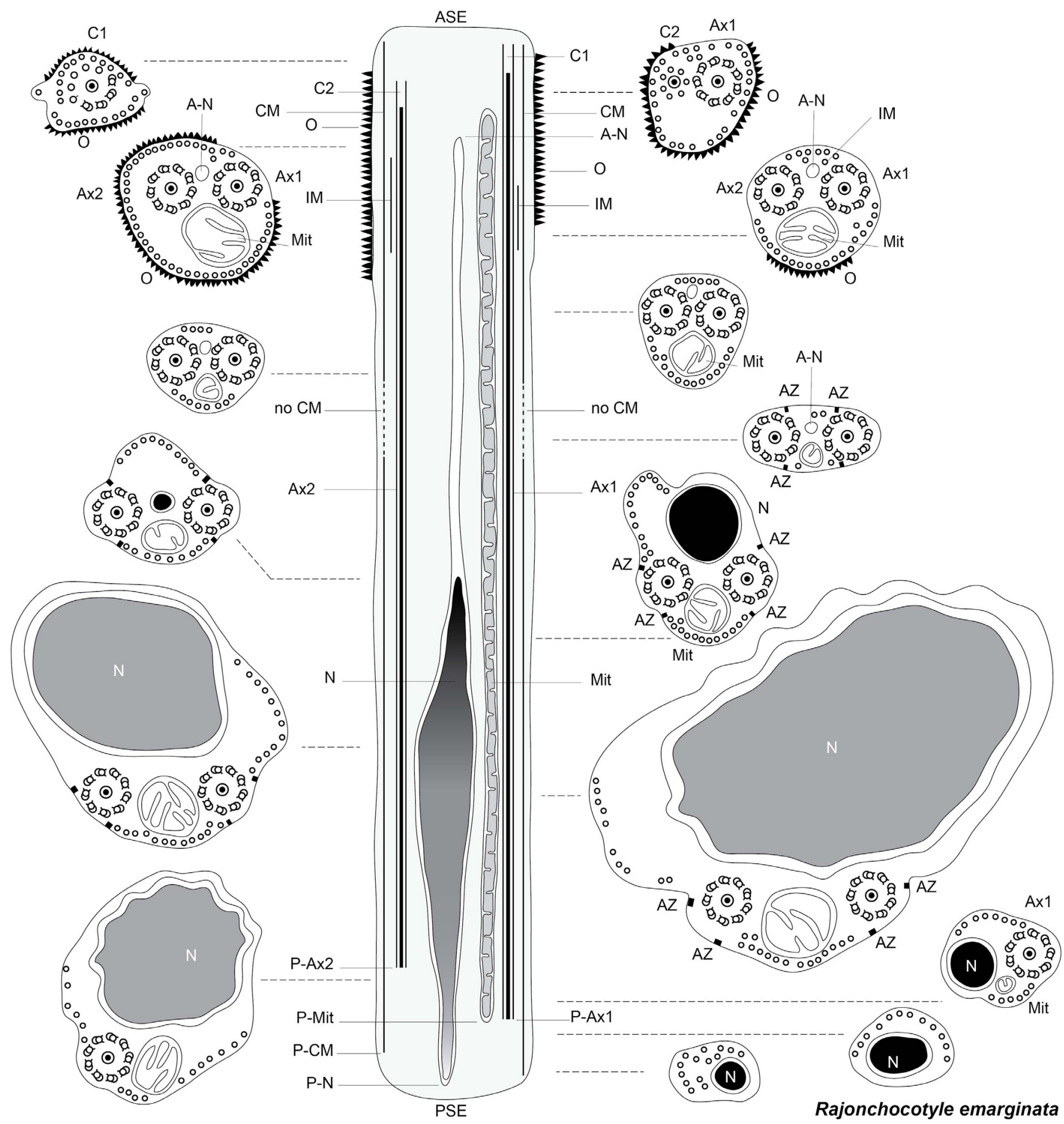

Figure 14. Schematic reconstruction of the spermatozoon of Rajonchocotyle emarginata.

which they were found. The flat sections described here in the spermatozoon of Callorhynchocotyle callorhynchi are reminiscent of what is called, in urodele amphibians, an "undulating membrane" [3,23]. This structure is different from all other cases found in monogeneans since it includes the nucleus and a single axoneme, with a flattened part between them with longitudinal microtubules; we have no information whether this structure is functional or not, i.e. whether it has a special role in the movement of the spermatozoon. We consider it to be an autapomorphy of Callorhynchocotyle, and we point out that, given the current state of knowledge on hexabothriid sperm, it is not a synapomorphy of the Hexabothriidae since it was not found in Rajonchocotyle emarginata. We also point out that it does not resemble and is not homologous to the undulating membrane of Gotocotyla and the lateral flanges of certain other polyopisthocotyleans. 


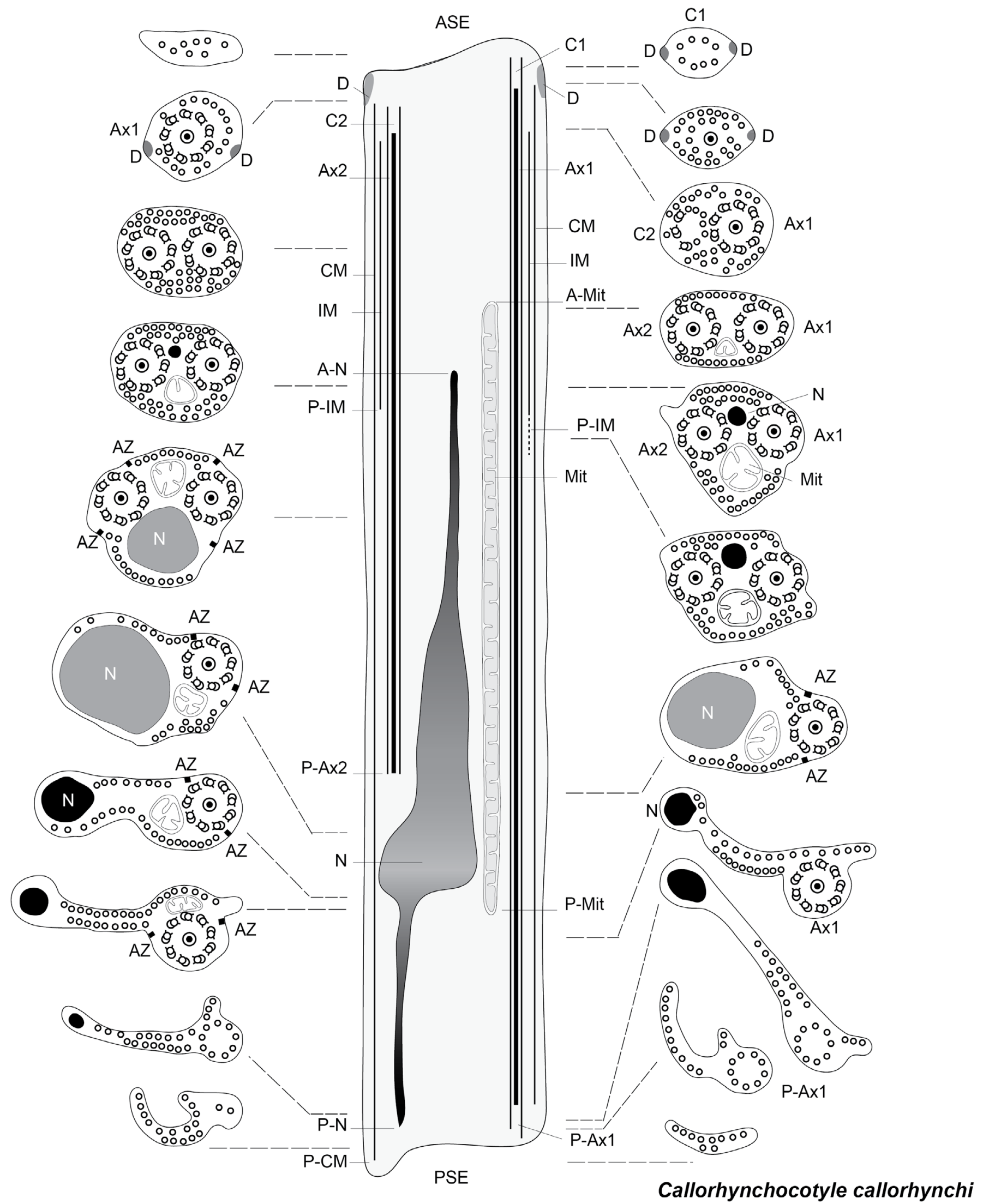

Figure 15. Schematic reconstruction of the spermatozoon of Callorhynchocotyle callorhynchi. 


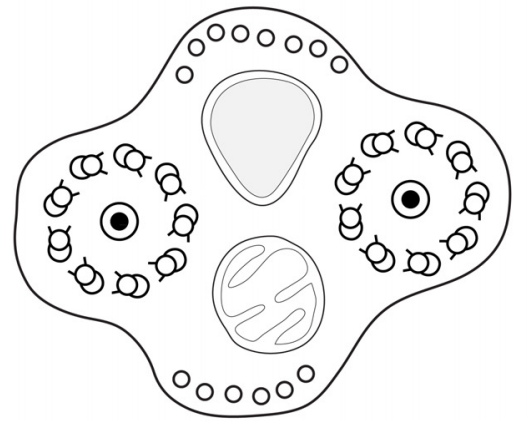

Digenea

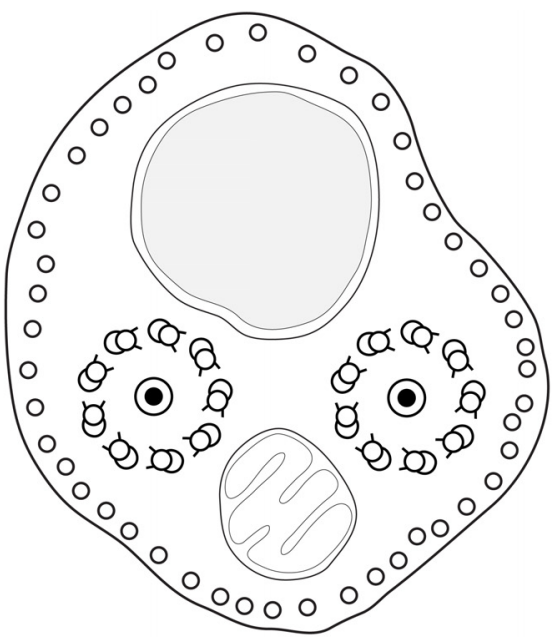

Polyopisthocotylea
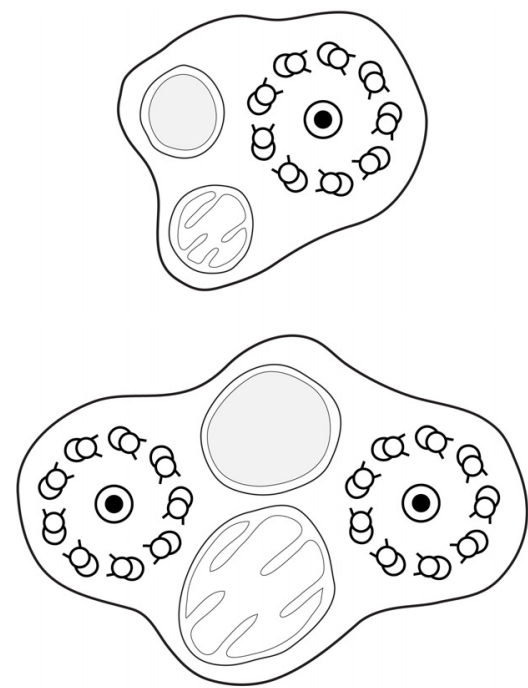

Monopisthocotylea

Figure 16. Diagrams of spermatozoa (redrawn from Justine, 1991 [35]). Caption adapted from original caption of figure. Diagrams were drawn from original micrographs of transverse sections. Digenea. Dorsal and ventral microtubules are present (proposed as a synapomorphy for the Cercomeridea). There are no lateral microtubules (symplesiomorphic compared with the synapomorphy for the polyopisthocotylean Monogenea). Polyopisthocotylea. Dorsal and ventral microtubules are present (synapomorphy for Cercomeridea). Note the presence of lateral microtubules (proposed as a synapomorphy for the Polyopisthocotylea). Monopisthocotylea (uniflagellate and biflagellate). Microtubules are absent from the principal region of the spermatozoon, which is interpreted as (i) the absence of dorsal and ventral microtubules, a reversal of the synapomorphy for the Cercomeridea; and (ii) the absence of lateral microtubules, the symplesiomorphic state versus the synapomorphy for the Polyopisthocotylea.

Various modifications of the nucleus shape, especially in cross sections, have been described. These include a crescent-shaped nucleus partially surrounding the axonemes, in Discocotyle sagittata, an annular nucleus completely surrounding the axonemes in Concinnocotyla australensis, and a special polygonally shaped nucleus in Atriaster spp. (references in Table 1). These variations should be considered autapomorphies of the taxa in which they were found. It is possible that variations of the structure of the anterior and posterior extremities of the spermatozoon provide additional structures useful for phylogenies [89], but this information is often lacking in published papers.

\section{Significance of variations of sperm ultrastructure within the Neodermata and the Polyopisthocotylea}

The Neodermata, which include all major groups of parasitic Platyhelminthes, i.e. the Digenea, Aspidogastrea, Eucestoda, Gyrocotylidea, Amphilinidea, Polyopisthocotylea, and Monopisthocotylea (the latter two often considered as forming the Monogenea) are characterised by spermatozoal synapomorphy, the proximo-distal fusion of axonemes during spermiogenesis [35]. Associated with this process is the presence of a characteristic structure termed the zone of differentiation [35,39]. The spermatozoon of the Neodermata has typically two axonemes and longitudinal peripheral microtubules [35,39].
Within the Neodermata, Justine (1991) [35] considered that there was a plesiomorphic pattern, with two axonemes and ventral and dorsal microtubules in the "principal region" of the spermatozoon, i.e. the region which contains the nucleus; it should be kept in mind that since the sperm of the Neodermata is "inverted", the region with the nucleus is posterior [35,39]. This plesiomorphic pattern is found in the Digenea and Cestoda. Two synapomorphies, defining major groups, were proposed: absence of the dorsal and ventral microtubules for the Monopisthocotylea, and presence of additional lateral microtubules for the Polyopisthocotylea. Figure 16 was drawn from Figure 5 in the 1991 paper by Justine [35].

For the Polyopisthocotylea, the synapomorphy "presence of lateral microtubules in the principal region of the spermatozoon" was defined by Justine in $1991[34,35,38,39]$. It was used in the two major attempts to develop a phylogeny of the monogeneans by Boeger \& Kritsky in 1993 [12] and 2001 [14]; we will discuss mainly the more recent of these papers [14] because it includes the matrix. According to Boeger \& Kritsky [14], this sperm synapomorphy was one of the six synapomorphies uniting the Polyopisthocotylea. It was used as character number 64 in their analysis as "lateral microtubules in the spermatozoon principal region of" and was character change 132 in their hypothesis [14]. Apomorphic state "present" was considered one of the six character changes that separates the Heteronchoinea (= Polyopisthocotylea) from the rest of the monogenes, considered as Polyonchoinea (= Monopisthocotylea); for 
Table 2. State of character "presence of lateral microtubules in principal region of spermatozoon" in families of the Polyopisthocotylea. A comparison between the state used in Boeger \& Kritsky (2001)'s phylogeny [14] and the actual information which was available at that time (see Table 1) and current information after present paper.

\begin{tabular}{|c|c|c|c|c|}
\hline Family & $\begin{array}{l}\text { State in Boeger } \\
\text { \& Kritsky, 2001, } \\
\text { Appendix } 10.2\end{array}$ & $\begin{array}{l}\text { Actual information } \\
\text { (according to Table 1) }\end{array}$ & Comments & $\begin{array}{l}\text { Current information } \\
\text { (according to present paper) }\end{array}$ \\
\hline Polystomatidae & 1 & 0 or 1 & over-generalization & \\
\hline Sphyranuridae & 1 & dubious & over-generalization & \\
\hline Chimaericolidae & 1 & unknown & over-generalization & state $=0$ \\
\hline Diclybothriidae & 1 & unknown & over-generalization & \\
\hline Hexabothriidae & 1 & dubious & over-generalization & state $=0$ \\
\hline Pterinotrematidae & 1 & 0 & error & \\
\hline Mazocraeidae & 1 & 1 & confirmed & \\
\hline Hexostomatidae & 1 & 1 & confirmed & \\
\hline Plectanocotylidae & 1 & 1 & confirmed & \\
\hline Mazoplectidae & 1 & unknown & over-generalization & \\
\hline Discocotylidae & 1 & 1 & confirmed & \\
\hline Diplozoidae & 1 & 1 & $\begin{array}{l}\text { homology uncertain - } \\
\text { different sperm structure }\end{array}$ & \\
\hline Diclidophoridae & 1 & 1 & confirmed & \\
\hline Anthocotylidae & 1 & unknown & over-generalization & \\
\hline Gastrocotylidae & 1 & 1 & confirmed & \\
\hline Chauhaneidae & 1 & 1 & confirmed & \\
\hline Protomicrocotylidae & 1 & 1 & confirmed & \\
\hline Gotocotylidae & 1 & 1 & confirmed & \\
\hline Microcotylidae & 1 & 1 & $\begin{array}{l}\text { several genera and species - } \\
\text { confirmed in all }\end{array}$ & \\
\hline Heteraxinidae & 1 & 1 & confirmed & \\
\hline Allopyragraphoridae & 1 & unknown & over-generalization & \\
\hline Diplasiocotylidae & 1 & unknown & over-generalization & \\
\hline Axinidae & 1 & 0 & error & \\
\hline Pyragraphoridae & 1 & 1 & confirmed & \\
\hline Montschadskyellidae & $?$ & unknown & absence of information confirmed & \\
\hline Pseudodiclidophoridae & 1 & unknown & over-generalization & \\
\hline Neothoracotylidae & 1 & unknown & over-generalization & \\
\hline Bychowskycotylidae & 1 & unknown & over-generalization & \\
\hline Allodiscocotylidae & 1 & unknown & over-generalization & \\
\hline Rhinecotylidae & 1 & unknown & over-generalization & \\
\hline Heteromicrocotylidae & 1 & unknown & over-generalization & \\
\hline Octomacridae & 1 & 1 & confirmed & \\
\hline Pseudomazocraeidae & 1 & 1 & confirmed & \\
\hline
\end{tabular}

equivalences between Polyopisthocotylea and Monopisthocotylea and between Heteronchoinea and Polyonchoinea see Table 1 in [75].

The present findings introduce an important change in the character matrix since this character was not found in the present study in the Chimaericolidae and Hexabothriidae, two of the most basal groups in the Polyopisthocotylea. Our knowledge of sperm structure in hexabothriids was limited to Erpocotyle catenulata; however, the published observation on this species by Tuzet \& Ktari in 1971 [105] is a single micrograph, somewhat fuzzy, of spermatozoa which are clearly altered with open membranes; peripheral microtubules are present, but the presence of lateral microtubules in sections with a nucleus cannot be ascertained. We thus conclude that the character "lateral microtubules in principal region of spermatozoon" is not present in the hexabothriid species studied so far, which belong to three genera, Erpocotyle, Callorhynchocotyle and Rajonchocotyle.

Moreover, careful re-analysis of accounts of sperm structure in the Polystomatidae shows that this character was not general in this family. It can be found in Concinnocotyla australensis, but cannot be seen in any of the photographs of spermatozoa of Pseudodiplorchis americanus or Polystoma sp.; in Polystoma spratti, the 


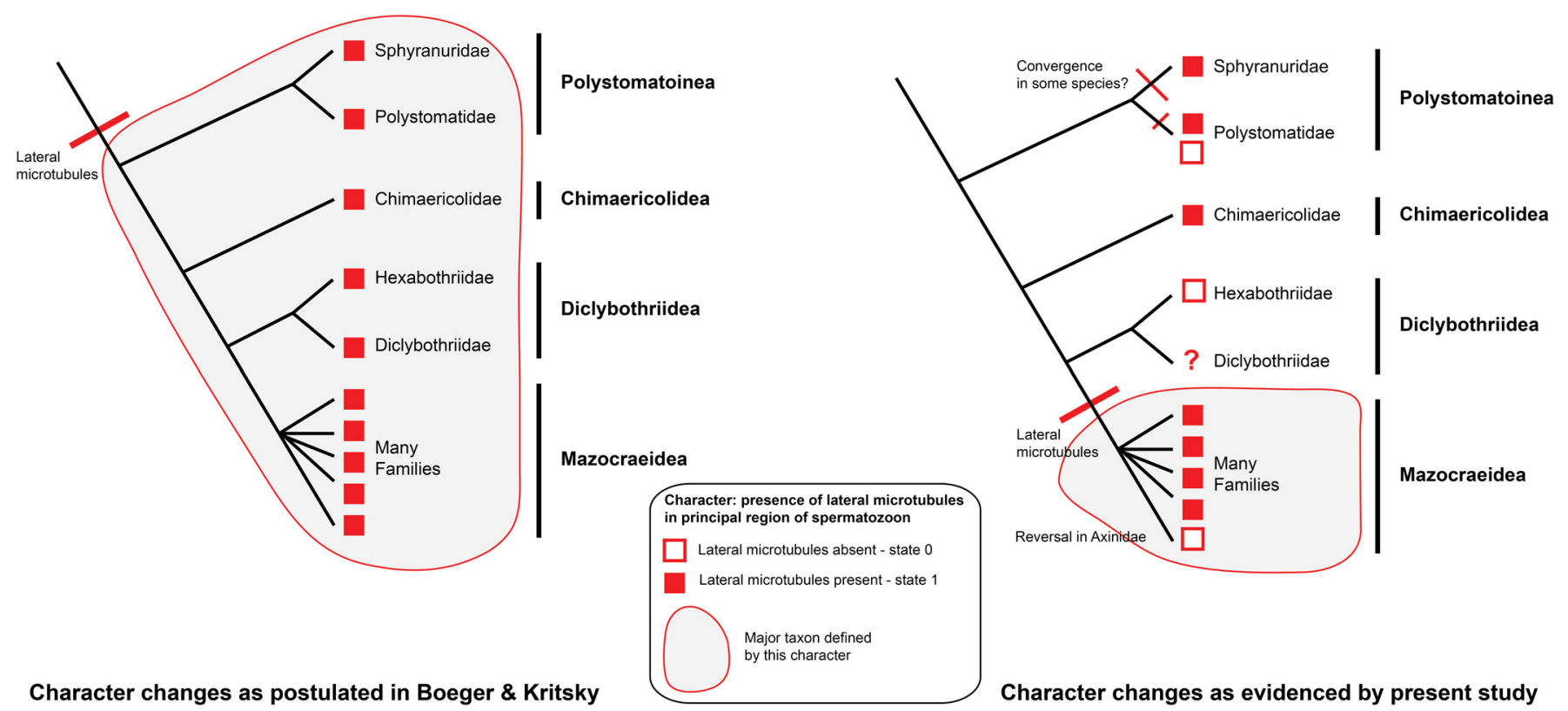

Figure 17. Interpretation of synapomorphies of spermatozoa, placed on a phylogeny of the Polyopisthocotylea. Left: Character changes as postulated in Boeger \& Kritsky (2001) [14]. The taxon defined by the character "presence of lateral microtubules in principal region of spermatozoon" is the Polyopisthocotylea as a whole. Right: Character changes as evidenced by present study. The taxon defined by the character "presence of lateral microtubules in principal region of spermatozoon" is restricted to the Mazocraeidea.

microtubules at the level of the nucleus never form a complete row (references in Table 1). For the Sphyranuridae, our knowledge is limited to observations without illustrations [34]. Interpretation of the significance of presence and absence of the character in the Polystomatoinea would need additional observations; we provisionally consider that presence of the row of microtubules in certain polystome species has its origin in independent evolutionary events or convergences.

It thus appears that the apomorphic character "presence of lateral microtubules in the principal region of the spermatozoon" is not a synapomorphy of the Polyopisthocotylea as a whole.

\section{Discrepancies between actual data and the matrix of Boeger \& Kritsky (2001)}

A close examination of the character matrix in Boeger \& Kritsky [14] shows that the character state was, in many cases, not coded in accordance with the data available at the time of publication of this paper (2001). The matrix includes 57 lines; for the Polyopisthocotylea, 33 families are listed, and the character state was coded as " 1 " (presence of lateral microtubules) in 32 of them - the only exception was the Montschadskyellidae, coded as "?", which was and is still correct. A comparison with Table 1 shows that the coding was correct in 15 families (i.e. character state "1" was actually visible in published papers), but that 13 families were erroneously coded " 1 " whereas the character state was unknown. Moreover, for two families, Pterinotrematidae and Axinidae, the character was coded as "1" whereas published information was
0. We interpret these discrepancies as "over-generalization", i.e. a character state common in a group was coded for all members of the group, while it was in fact present only for some members. In the matrix by Boeger \& Kritsky [14], over-generalization concerns 15 polyopisthocotylean families amongst 33 (Table 2). The inspiration for the over-generalization of spermatological characters can probably be found in the papers on sperm structure by Justine $[34,35,39,46]$, who generally considered that sperm structure was homogeneous in the Polyopisthocotylea. Over-generalization and errors in the analysis of sperm characters probably calls for a re-examination of some other (non-spermatological) characters in the matrix of Boeger \& Kritsky [14]. However, it should be outlined that small corrections in spermatological characters in the matrix would probably not change the resulting tree and the phylogeny proposed by Boeger \& Kritsky [14].

\section{Re-interpretation of the major synapomorphies of the Monogenea in light of this study}

Hypotheses for the phylogeny of the Neodermata, the parasitic Platyhelminthes which include the Cestoda, Trematoda and Monogenea, have been based, successively or simultaneously, on four sets of characters over the years: (1) Traditional morphology; (2) Sperm ultrastructure; (3) Sequences of selected parts of the genome; (4) Complete mitochondrial genomes. We can expect that the next step will be the comparison of complete genomes; however, we believe that main morphological or spermatological characters are still to be considered even in the future. 
Major phylogenies based on morphology by Boeger \& Kritsky (with the inclusion of several characters of spermatozoa) have concluded on monophyly of the Monogenea [12,14]. However, spermatological characters do not provide evidence for monophyly $[35,39,40,42,43,46]$ and a reexamination of morphological characters found the monogenean non-monophyletic [22]. Molecular analyses based on $18 \mathrm{~S}$ or $28 \mathrm{~S}$ partial gene sequences $[74,75,79]$ found the Monopisthocotylea and the Polyopisthocotylea each to be monophyletic, but the Monogenea were paraphyletic; an exception is the analysis by Lockyer et al. (2003) [69] in which the Monogenea were monophyletic. Complete mitochondrial genomes are known for about 40 species of Platyhelminthes [100], including a dozen monogeneans [4,30,64,80-82,111-114]. Ye et al. (2014) [111] compared the mitogenomes of 10 species and found that Polyopisthocotylea and Monopisthocotylea had distinct gene arrangements. Therefore, molecular data currently available still point towards non-monophyly of the Monogenea. It is important to mention that all mitogenomes available for the Polyopisthocotylea are from a single superfamily, the Mazocraeidea, a situation which is reminiscent of the database on sperm ultrastructure before the present study.

In Figure 17, we try to reconcile the present information with a general phylogeny of the Polyopisthocotylea. We consider, finally, that the apomorphic character "presence of lateral microtubules in the principal region of the spermatozoon" is a synapomorphy of the Mazocraeidea. An investigation of the Diclybothriidae, the sister-group of the Hexabothriidae would be of interest; investigations in additional hexabothriids would be useful too, since our present knowledge is based only on three genera among the fifteen included in the family.

We believe that the present findings and interpretation are important not only for the polyopisthocotylean monogeneans, but for our understanding of phylogeny in the whole Neodermata.

Acknowledgments. The authors would like to thank in particular Dr Willy Hemmingsen, University of Troms $\varnothing$ (Norway), and the staff of the RV 'Johan Ruud' of the University for their help with the fishing and material collection, and Dr Cecile Reed, University of Cape Town (South Africa) for material collection. The authors are grateful to the staff of the Centre of Electron Microscopy, I.D. Papanin Institute for Biology of Inland Waters, Russian Academy of Sciences, Borok, Russia, for technical assistance. This research was performed in the framework of the state assignment of FASO Russia (theme No. 0122-2014-0007) and supported in part by RFBR (Project no. 15-04-02890-a to LGP). This paper was reviewed by three anonymous reviewers; the authors express their gratitude for the quality and detail of their comments.

\section{Conflict of interest}

The Editor-in-Chief of Parasite is one of the authors of this manuscript. COPE (Committee on Publication Ethics, http://publicationethics.org), to which Parasite adheres, advises special treatment in these cases. In this case, the peer-review process was handled by an Invited Editor, Jerôme Depaquit.

\section{Abbreviations for all figures}

\begin{tabular}{|c|c|}
\hline $\mathrm{A}-\mathrm{CM}$ & $\begin{array}{l}\text { Anterior extremity of cortical microtu- } \\
\text { bules }\end{array}$ \\
\hline A-IM & $\begin{array}{l}\text { Anterior extremity of internal micro- } \\
\text { tubules }\end{array}$ \\
\hline $\mathrm{AM}$ & Arching membrane \\
\hline A-Mit & Anterior extremity of mitochondrion \\
\hline $\mathrm{A}-\mathrm{N}$ & Anterior extremity of nucleus \\
\hline ASE & Anterior spermatozoon extremity \\
\hline$A x, A x 1, A x 2$ & Axonemes \\
\hline $\mathrm{AZ}$ & Attachment zone \\
\hline $\mathrm{C}, \mathrm{C} 1, \mathrm{C} 2$ & Centrioles \\
\hline $\mathrm{CM}$ & Cortical microtubules \\
\hline $\mathrm{D}$ & Dense zone \\
\hline $\mathrm{FF}$ & Free flagellum \\
\hline IB & Intercentriolar body \\
\hline IM & Internal microtubules \\
\hline M & $\begin{array}{l}\text { (in micrographs), Mit (in diagrams) } \\
\text { Mitochondrion }\end{array}$ \\
\hline MCE & Median cytoplasmic process \\
\hline MT & microtubules \\
\hline $\mathrm{N}$ & Nucleus \\
\hline $\mathrm{O}$ & Ornamentation on membrane \\
\hline P-Ax1, P-Ax2 & Posterior extremity of axoneme 1,2 \\
\hline PSE & Posterior spermatozoon extremity \\
\hline $\mathrm{P}-\mathrm{CM}$ & $\begin{array}{l}\text { Posterior extremity of cortical micro- } \\
\text { tubules }\end{array}$ \\
\hline P-IM & $\begin{array}{l}\text { Posterior extremity of internal micro- } \\
\text { tubules }\end{array}$ \\
\hline P-Mit & Posterior extremity of mitochondrion \\
\hline $\mathrm{P}-\mathrm{N}$ & Posterior extremity of nucleus \\
\hline SR & Striated root \\
\hline
\end{tabular}

\section{References}

1. Bâ CT, Marchand B, Mattei X. 1991. Demonstration of the orientation of the Cestodes spermatozoon illustrated by the ultrastructural study of spermiogenesis of a Cyclophyllidea: Thysaniezia ovilla, Rivolta, 1874. Journal of Submicroscopic Cytology and Pathology, 23, 606-612.

2. Bâ CT, Marchand M. 1995. Spermiogenesis, spermatozoa and phyletic affinities in the Cestoda, in: Advances in spermatozoal phylogeny and taxonomy, Mémoires du Muséum national d'Histoire Naturelle, 166, Jamieson BGM, Ausio J, Justine J-L, Eds. p. 87-95.

3. Baccetti B, Afzelius BA. 1976. The Biology of the Sperm Cell. Basel: Karger. 254 pp.

4. Bachmann L, Fromm B, Patella de Azambuja L, Boeger WA. 2016. The mitochondrial genome of the egg-laying flatworm Aglaiogyrodactylus forficulatus (Platyhelminthes: Monogenoidea). Parasites \& Vectors, 9(1), 285.

5. Bakhoum AJ, Quilichini Y, Miquel J, Feliu C, Bâ CT, Marchand B. 2014. Collyricloides massanae (Digenea, Collyriclidae): spermatozoon ultrastructure and phylogenetic importance. Parasite, 21, 59. 
6. Bakhoum AJS, Miquel J, Ndiaye PI, Justine J-L., Falchi A, Bâ CT, Marchand B, Quilichini Y. 2017. Advances in spermatological characters in the Digenea: Review and proposal of spermatozoa models and their phylogenetic importance. Advances in Parasitology, 98, 111-165.

7. Bakhoum AJS, Quilichini Y, Justine J-L., Bray RA, Bâ CT, Marchand B. 2015. Ultrastructural study of sperm cells in Acanthocolpidae: the case of Stephanostomum murielae and Stephanostomoides tenuis (Digenea). PeerJ, 3,744 .

8. Bakhoum AJS, Quilichini Y, Justine J-L., Bray RA, Miquel J, Feliu C, Bâ CT, Marchand B. 2015. First spermatological study in the Atractotrematidae (Digenea, Haploporoidea): the case of Atractotrema sigani, intestinal parasite of Siganus lineatus. Parasite, 22, 26.

9. Baptista-Farias MFD, Kohn A, Barth OM. 1995. Ultrastructural aspects of spermatogenesis in Metamicrocotyla macracantha (Alexander, 1954) Koratha, 1955 (Monogenea; Microcotylidae). Memórias do Instituto Oswaldo Cruz, 90, 597-604.

10. Baptista-Farias MFD, Kohn A, Cohen SC. 1999. Spermatogenesis and spermiogenesis in Microcotyle sp. (Microcotylidae, Monogenea). Journal of Parasitology, $85,832-838$

11. Bekkouche Z, Fournier A, Peyrière M. 1974. Différences ultrastructurales entre Monogènes Monopisthocotylea et Polyopisthocotylea, parasites d'Amphibiens. in: Proceedings of 3rd International Congress on Parasitology. Munich: Facta.

12. Boeger WA, Kritsky DC. 1993. Phylogeny and a revised classification of the Monogenoidea Bychowsky, 1937 (Platyhelminthes). Systematic Parasitology, 26, 1-32.

13. Boeger WA, Kritsky DC. 1997. Coevolution of the Monogenoidea (Platyhelminthes) based on a revised hypothesis of parasite phylogeny. International Journal for Parasitology, 27, 1495-1511.

14. Boeger WA, Kritsky DC. 2001. Phylogenetic relationships of the Monogenoidea, in: Interrelationships of the Platyhelminthes, Littlewood DTJ, Bray RA, Eds. Taylor and Francis: London \& New York. p. 92-102.

15. Bovet J. 1967. Contribution à la morphologie et à la biologie de Diplozoon paradoxum v. Nordmann, 1832. Bulletin de la Société Neuchâteloise des Sciences Naturelles, 90, 63-159.

16. Brunanská M, Mackiewicz JS, Poddubnaya Larisa G. 2017. Spermatological characteristics of the enigmatic monogenean Dictyocotyle coeliaca Nybelin, 1941 (Monopisthocotylea: Monocotylidae) reveal possible adaptation to endoparasitism. Acta Parasitologica, 62(1), 110-120.

17. Brunanská M, Poddubnaya LG. 2017. Spermiogenesis and sperm ultrastructure in Calicotyle affinis Scott, 1911 (Platyhelminthes, Monogenea, Monopisthocotylea, Monocotylidae). Helminthologia, 54, 348-357.

18. Cable J, Tinsley RC. 1993. The ultrastructure of spermatogenesis and spermatozoa in Pseudodiplorchis americanus (Monogenea: Polystomatidae). Canadian Journal of Zoology, 71, 1609-1619.

19. Cable J, Tinsley RC. 2001. Ultrastructure of spermiogenesis and spermatozoa of Discocotyle sagittata (Monogenea: Polyopisthocotylea: Discocotylinea). Folia Parasitologica, 48, 209-216.

20. Ehlers U. 1985. Das Phylogenetische System der Plathelminthes. Stuttgart: G. Fischer. 317 pp.

21. Ehlers U. 1986. Comments on a phylogenetic system of the Platyhelminthes. Hydrobiologia, 132, 1-12.
22. Euzet L, Combes C. 2003. Some controversial questions regarding Monogenea, in: Taxonomie, écologie et évolution des Métazoaires parasites. Taxonomy, Ecology and Evolution of Metazoan Parasites. Livre-hommage à Louis Euzet, Combes C, Jourdane J, Eds. Presses Universitaire de Perpignan: Perpignan. p. 303-320.

23. Fawcett DW. 1970. A comparative view of sperm ultrastructure. Biology of Reproduction, 2(Suppl 2), 90-127.

24. Fournier A, Justine J- L. 1994. Ultrastructure of spermiogenesis and spermatozoa in Euzetrema knoepffleri (Platyhelminthes, Monogenea). Parasite, 1, 123-126.

25. Franzén A. 1956. On spermiogenesis, morphology of the spermatozoon, and biology of fertilization among invertebrates. Zoologiske Bidrag fran Uppsala, 31, 355-482.

26. Gibson DI. 2010. Polyopisthocotylea. Accessed through: World Register of Marine Species at http://www. marinespecies.org/aphia.php? $\mathrm{p}=$ taxdetails\&id $=119220$ on 2016-02-24.

27. Halton DW, Hardcastle A. 1976. Spermatogenesis in a monogenean, Diclidophora merlangi. International Journal for Parasitology, 6, 43-53.

28. Hathaway MA, Hathaway RP, Kritsky DC. 1995. Spermatogenesis in Octomacrum lanceatum (Monogenoidea Oligonchoinea Mazocraeidae). International Journal for Parasitology, 25, 913-922.

29. Hoberg EP, Mariaux J, Justine J- L, Brooks DR, Weekes PJ. 1997. Phylogeny of the orders of the Eucestoda (Cercomeromorphae) based on comparative morphology: historical perspectives and a new working hypothesis. Journal of Parasitology, 83, 1128-1147.

30. Huyse T, Plaisance L, Webster BL, Mo TA, Bakke TA, Bachmann L, Littlewood DTJ. 2007. The mitochondrial genome of Gyrodactylus salaris (Platyhelminthes: Monogenea), a pathogen of Atlantic salmon (Salmo salar). Parasitology, 134, 739-747.

31. Jamieson BGM, Justine J-L. 2016. Spermatozoa, Spermatogenesis and Fertilization in Schistosoma, in: Schistosoma: Biology, Pathology and Control, Jamieson BGM, Ed. CRC Press: Boca Raton, FL. p. 300-319.

32. Jovelin R, Justine J- L. 2001. Phylogenetic relationships within the polyopisthocotylean monogeneans (Platyhelminthes) inferred from partial $28 \mathrm{~S}$ rDNA sequences. International Journal for Parasitology, 31, 393-401.

33. Justine J- L. 1985. Étude ultrastructurale comparée de la spermiogenèse des Digènes et des Monogènes (Plathelminthes). Relations entre la morphologie du spermatozoïde, la biologie de la fécondation et la phylogénie. Thèse d'Etat. Université des Sciences et Techniques du Languedoc (Montpellier II), Montpellier, France.

34. Justine J-L. 1991. Cladistic study in the Monogenea (Platyhelminthes), based upon a parsimony analysis of spermiogenetic and spermatozoal ultrastructural characters. International Journal for Parasitology, 21, 821-838.

35. Justine J-L. 1991. Phylogeny of parasitic Platyhelminthes: a critical study of synapomorphies proposed on the basis of the ultrastructure of spermiogenesis and spermatozoa. Canadian Journal of Zoology, 69, 14211440.

36. Justine J-L. 1991. The spermatozoa of the schistosomes and the concept of progenetic spermiogenesis, in: Comparative Spermatology 20 Years After, Baccetti B, Ed. Raven Press: New York. p. 977-979.

37. Justine J-L. 1992. Ultrastructure of spermiogenesis, spermatozoa and the tegument in Atriaster sp. (Platyhelminthes, Monogenea, Polyopisthocotylea, Microcotylidae). Zoologica Scripta, 21, 231-238. 
38. Justine J-L. 1993. Phylogénie des Monogènes basée sur une analyse de parcimonie des caractères de l'ultrastructure de la spermiogenèse et des spermatozoïdes incluant les résultats récents. Bulletin Français de la Pêche et de la Pisciculture, 328, 137-155.

39. Justine J-L. 1995. Spermatozoal ultrastructure and phylogeny of the parasitic Platyhelminthes, in: Advances in spermatozoal phylogeny and taxonomy. Mémoires du Muséum National d'Histoire Naturelle, 166, Jamieson BGM, Ausio J, Justine J-L, Eds. p. 55-86.

40. Justine J-L. 1998. Non-monophyly of the monogeneans? International Journal for Parasitology, 28, 1653-1657.

41. Justine J-L. 1998. Spermatozoa as phylogenetic characters for the Eucestoda. Journal of Parasitology, 84, 385408.

42. Justine J-L. 2001. Spermatozoa as phylogenetic characters for the Platyhelminthes, in: Interrelationships of the Platyhelminthes, Littlewood DTJ, Bray RA, Eds. Taylor and Francis: London \& New York. p. 231-238.

43. Justine J- L. 2003. Ultrastructure des spermatozoïdes et phylogénie des Neodermata, in: Taxonomie, écologie et évolution des Métazoaires parasites. Taxonomy, Ecology and Evolution of Metazoan Parasites. Livre-hommage à Louis Euzet, Combes C, Jourdane J, Eds. Presses Universitaires de Perpignan: Perpignan. p. 359-380.

44. Justine J-L, Afzelius BA, Malmberg G, Mattei X. 1993. Ultrastructure of spermiogenesis in Acanthocotyle and Myxinidocotyle (Platyhelminthes, Monogenea, Acanthocotylidae). Acta Zoologica (Stockholm), 74, 119-126.

45. Justine J-L., Jamieson BGM, Southgate VR. 1993. Homogeneity of sperm structure in six species of Schistosomes (Digenea, Platyhelminthes). Annales de Parasitologie Humaine et Comparée (Paris), 68, 185-187.

46. Justine J-L, Lambert A, Mattei X. 1985. Spermatozoon ultrastructure and phylogenetic relationships in the monogeneans (Platyhelminthes). International Journal for Parasitology, 15, 601-608.

47. Justine J-L., Le Brun N, Mattei X. 1985. The aflagellate spermatozoon of Diplozoon (Platyhelminthe: Monogenea: Polyopisthocotylea). A demonstrative case of relationship between sperm ultrastructure and biology of reproduction. Journal of Ultrastructure Research, 92, 47-54.

48. Justine J-L., Le Brun N, Mattei X. 1985. First report of aflagellate spermatozoon in a parasitic Platyhelminthe, found in the monogenean Diplozoon gracile (Polyopisthocotylea, Diplozoidae) . Annales de Parasitologie Humaine et Comparée (Paris) , 60, 761-762.

49. Justine J-L., Mattei X. 1982. Présence de spermatozoïdes à un seul axonème dans trois familles de Monogènes Monopisthocotylea: Ancyrocephalidae, Diplectanidae et Monocotylidae. Annales de Parasitologie Humaine et Comparée (Paris), 57, 419-420.

50. Justine J-L., Mattei X. 1983. Comparative ultrastructural study of spermiogenesis in Monogeneans (Flatworms). 2. Heterocotyle (Monopisthocotylea: Monocotylidae). Journal of Ultrastructure Research, 84, 213-223.

51. Justine J-L., Mattei X. 1983. Comparative ultrastructural study of spermiogenesis in Monogeneans (Flatworms). 3. Two species of Amphibdelloides (Monopisthocotylea: Amphibdellatidae). Journal of Ultrastructure Research, 84, 224-237.

52. Justine J-L., Mattei X. 1983. Étude ultrastructurale comparée de la spermiogenèse des Monogènes. 1. Megalocotyle (Monopisthocotylea: Capsalidae). Journal of Ultrastructure Research, 82, 296-308.
53. Justine J-L., Mattei X. 1984. Comparative ultrastructural study of spermiogenesis in Monogeneans (Flatworms). 4. Diplectanum (Monopisthocotylea Diplectanidae). Journal of Ultrastructure Research, 88, 77-91.

54. Justine J-L., Mattei X. 1984. Ultrastructure du spermatozoïde du Monogène Hexostoma (Polyopisthocotylea, Hexostomatidae). Annales de Parasitologie Humaine et Comparée (Paris), 59, 227-229.

55. Justine J-L., Mattei X. 1985. Particularités ultrastructurales des spermatozoïdes de quelques Monogènes Polyopisthocotylea. Annales des Sciences Naturelles (Zoologie), 7, 143-152.

56. Justine J-L., Mattei X. 1985. A spermatozoon with undulating membrane in a parasitic Flatworm, Gotocotyla (Monogenea, Polyopisthocotylea, Gotocotylidae). Journal of Ultrastructure Research, 90, 163-171.

57. Justine J-L., Mattei X. 1985. Ultrastructure de la spermiogenèse et du spermatozoïde de Loimosina wilsoni et affinités phylétiques des Loimoidae (Plathelminthes, Monogenea, Monopisthocotylea). Zoologica Scripta, 14, 169-175.

58. Justine J-L., Mattei X. 1985. Ultrastructure du spermatozoïde de trois Monogènes Polyopisthocotylea: Cemocotyle,Heteraxine etHeteraxinoides. Annales de Parasitologie Humaine et Comparée (Paris), 60, 659-663.

59. Justine J-L, Mattei X. 1986. Comparative ultrastructural study of spermiogenesis in Monogeneans (Flatworms). 5. Calceostoma (Monopisthocotylea Calceostomatidae). Journal of Ultrastructure and Molecular Structure Research, 96, 54-63.

60. Justine J-L., Mattei X. 1986. Ultrastructural observations on fertilization in Dionchus remorae (Platyhelminthes, Monogenea, Dionchidae). Acta Zoologica (Stockholm), $67,97-101$.

61. Justine J-L, Mattei X. 1987. Phylogenetic relationships between the families Capsalidae and Dionchidae (Platyhelminthes, Monogenea, Monopisthocotylea) indicated by the comparative ultrastructural study of spermiogenesis. Zoologica Scripta, 16, 111-116.

62. Justine J-L., Mattei X. 1988. Bending of $9+$ "1" axonemes of flatworm spermatozoa in hypotonic media: an experimental study. Journal of Ultrastructure and Molecular Structure Research, 100, 31-38.

63. Justine J-L, Mattei X, Euzet L. 1991. Ultrastructure of spermatozoa in two monopisthocotylean monogeneans: Encotyllabe sp. (Capsalidae) and Tetraonchoides sp. (Tetraonchoididae). Annales de Parasitologie Humaine et Comparée (Paris), 66, 173-178.

64. Kang S, Kim J, Lee J, Kim S, Min G-S., Park J-K. 2012. The complete mitochondrial genome of an ectoparasitic monopisthocotylean fluke Benedenia hoshinai (Monogenea: Platyhelminthes). Mitochondrial DNA, 23(3), 176-178.

65. Kritsky DC. 1976. [Observations on the ultrastructure of spermatozoa and spermiogenesis in the monogenean Gyrodactylus eucaliae Ikezaki et Hoffman, 1957]. Trudy Dal'nevostochnyi Nauchnyi Tsentralbiologo Pochvennyi Institut, Vladivostok, 34 (N.S), 70-74.

66. Le Brun N, Lambert A, Justine J-L. 1986. Oncomiracidium, morphogenèse du hapteur et ultrastructure du spermatozoïde de Pseudodactylogyrus anguillae (Yin et Sproston, 1948) Gussev, 1965 (Monogenea, Monopisthocotylea, Pseudodactylogyridae n. fam.). Annales de Parasitologie Humaine et Comparée (Paris), 61, 273284. 
67. Levron C, Miquel J, Oros M, Scholz T. 2010. Spermatozoa of tapeworms (Platyhelminthes, Eucestoda): advances in ultrastructural and phylogenetic studies. Biological Reviews, 85(3), 523-543.

68. Li M-M., Wang Z-L., Liu H-H., Wang X-Y. 2000. [Ultrastructure of spermatozoa in Polystoma sp. (Monogenea Polyopisthocotylea: Polystomatidae)]. Acta Zoologica Sinica, 46, 361-365.

69. Lockyer AE, Olson PD, Littlewood DTJ. 2003. Utility of complete large and small subunit rRNA genes in resolving the phylogeny of the Neodermata (Platyhelminthes): implications and a review of the cercomer theory. Biological Journal of the Linnean Society, 78, 155-171.

70. MacDonald S, Caley J. 1975. Sexual reproduction in the monogenean Diclidophora merlangi: tissue penetration by sperms. Zeitschrift für Parasitenkunde, 45, 323-334.

71. Malmberg G, Afzelius BA. 1990. Sperm ultrastructure in Myxinidocotyle and Acanthocotyle (Platyhelminthes, Monogenea, Acanthocotylidae). Zoologica Scripta, 19, 129-132.

72. Malmberg G, Lilliemark Y. 1993. Sperm ultrastructure of Isancistrum subulatae (Platyhelminthes: Monogenea: Gyrodactylidae). Folia Parasitologica, 40, 97-98.

73. Miquel J, Vilavella D, Swiderski Z, Shimalov VV, Torres J. 2013. Spermatological characteristics of Pleurogenidae (Digenea) inferred from the ultrastructural study of Pleurogenes claviger, Pleurogenoides medians and Prosotocus confusus. Parasite, 20, 28.

74. Mollaret I, Jamieson BGM, Adlard RD, Hugall A, Lecointre G, Chombard C, Justine J- L. 1997. Phylogenetic analysis of the Monogenea and their relationships with Digenea and Eucestoda inferred from 28S rDNA sequences. Molecular and Biochemical Parasitology, 90, 433-438

75. Mollaret I, Jamieson BGM, Justine J-L. 2000. Phylogeny of the Monopisthocotylea and Polyopisthocotylea (Platyhelminthes) inferred from $28 \mathrm{~S}$ rDNA sequences. International Journal for Parasitology, 30, 171-185.

76. Mollaret I, Justine J- L. 1997. Immunocytochemical study of tubulin in the $9+$ " 1 " sperm axoneme of a monogenean (Platyhelminthes), Pseudodactylogyrus sp. Tissue \& Cell, 29, 699-706.

77. Mollaret I, Lim LHS, Malmberg G, Afzelius B, Justine JL. 1998. Spermatozoon ultrastructure in two monopisthocotylean monogeneans from Malaysia: Pseudodactylogyroides marmoratae and Sundanonchus micropeltis. Folia Parasitologica, 45, 75-76.

78. Olson PD, Littlewood DTJ. 2002. Phylogenetics of the Monogenea - evidence from a medley of molecules. International Journal for Parasitology, 32, 233-244.

79. Olson PD, Tkach VV. 2005. Advances and trends in the molecular systematics of the parasitic Platyhelminthes, in: Advances in Parasitology. Academic Press. p. 165-243.

80. Park JK, Kim KH, Kang S, Kim W, Eom KS, Littlewood DTJ. 2007. A common origin of complex life cycles in parasitic flatworms: evidence from the complete mitochondrial genome of Microcotyle sebastis (Monogenea: Platyhelminthes). BMC Evolutionary Biology, 7, 11.

81. Perkins EM, Donnellan SC, Bertozzi T, Whittington ID. 2010. Closing the mitochondrial circle on paraphyly of the Monogenea (Platyhelminthes) infers evolution in the diet of parasitic flatworms. International Journal for Parasitology, 40, 1237-1245

82. Plaisance L, Huyse T, Littlewood DTJ, Bakke TA, Bachmann L. 2007. The complete mitochondrial DNA sequence of the monogenean Gyrodactylus thymalli
(Platyhelminthes: Monogenea), a parasite of grayling (Thymallus thymallus). Molecular and Biochemical Parasitology, 154(2), 190-194.

83. Poddubnaya LG, Hemmingsen W, Gibson DI. 2013. Ultrastructural characteristics of the vaginae of the basal monogenean Chimaericola leptogaster (Leuckart, 1830). Parasitology Research, 112(12), 4053-4064.

84. Poddubnaya LG, Hemmingsen W, Gibson DI. 2014. Clamp ultrastructure of the basal monogenean Chimaericola leptogaster (Leuckart, 1830) (Polyopisthocotylea: Chimaericolidae). Parasitology Research, 113(11), 402332.

85. Poddubnaya LG, Hemmingsen W, Gibson DI. 2016. Ultrastructural observations of the attachment organs of the monogenean Rajonchocotyle emarginata (Olsson, 1876) (Polyopisthocotylea: Hexabothriidae), a gill parasite of rays. Parasitology Research, 115(6), 2285-2297.

86. Poddubnaya LG, Hemmingsen W, Reed C, Gibson DI. 2015. Ultrastructural characteristics of the caeca of basal polyopisthocotylean monogeneans of the families Chimaericolidae and Hexabothriidae parasitic on cartilaginous fishes. Parasitology Research, 114(7), 2599-2610.

87. Poddubnaya LG, Hemmingsen W, Reed C, Gibson DI. 2017. Ultrastructural characteristics of the vitellarium of basal polyopisthocotylean monogeneans of the family Hexabothriidae, with comments on glycan vesicle development and its phylogenetic significance. Zoologischer Anzeiger, 266, 50-60.

88. Poddubnaya LG, Reed C, Gibson DI. 2015. The surface topography of Callorhynchocotyle callorhynchi (Manter, 1955) (Monogenea: Hexabothriidae), a parasite of the holocephalan fish Callorhinchus capensis. Parasitology Research, 114(9), 3393-3399.

89. Quilichini Y, Foata J, Marchand B. 2009. Ultrastructural study of spermiogenesis and the spermatozoon of Microcotyle pancerii (Monogenea: Polyopisthocotylea: Microcotylidae), parasite of Meagre Argyrosomus regius (Pisces: Teleostei). Journal of Parasitology, 95(2), 261270.

90. Rohde K. 1971. Phylogenetic origin of trematodes. Parasitologische Schriftenreihe, 21, 17-27.

91. Rohde K. 1975. Fine structure of the Monogenea, especially Polystomoides Ward. Advances in Parasitology, $13,1-33$.

92. Rohde K. 1980. Some aspects of the ultrastructure of Gotocotyla secunda and Hexostoma euthynni. Angewandte Parasitologie, 21, 32-48.

93. Rohde K, Watson NA. 1993. Spermatogenesis in Udonella (Platyhelminthes, Udonellidea) and the phylogenetic position of the genus. International Journal for Parasitology, 23, 725-735.

94. Rohde K, Watson NA. 1994. Spermiogenesis in Gonoplasius sp. (Monogenea, Polyopisthocotylea, Microcotylidae). Acta Parasitologica, 39, 111-116.

95. Rohde K, Watson NA. 1994. Ultrastructure of spermiogenesis and spermatozoa of Polylabroides australis (Platyhelminthes, Monogenea, Polyopisthocotylea, Microcotylidae). Parasite, 1, 115-122.

96. Santos CP, Lanfredi RM, Souto- Padrón T. 1997. Ultrastructure of spermatogenesis of Atriaster heterodus (Platyhelminthes, Monogenea, Polyopisthocotylea). Journal of Parasitology, 83, 1007-1014.

97. Sato M, Oh M, Sakoda K. 1967. Electron microscopic study of spermatogenesis in the lung fluke (Paragonimus miyazakii). Zeitschrift für Zellforschung und Mikroskopische-Anatomie, 77, 232-243. 
98. Schmahl G, Elwasila M. 1992. Fine structure of spermatogenesis in monopisthocotylean monogeneans (Macrogyrodactylus polypteri; Pseudodactylogyrus bini). Folia Parasitologica (Praha), 39, 19-31.

99. Schmahl G, Obiekezie A. 1991. Fine structure of spermatogenesis in polyopisthocotylid monogeneans (Protomicrocotyle ivoriensis, Gastrocotyle sp.). Parasitology Research, 77, 115-122.

100. Solà E, Álvarez-Presas M, Frías- López C, Littlewood DTJ, Rozas J, Riutort M. 2015. Evolutionary analysis of mitogenomes from parasitic and free-living flatworms. PLOS ONE, 10(3), e0120081.

101. Tappenden T, Kearn GC. 1990. Spermiogenesis and sperm ultrastructure in the monogenean parasite Acanthocotyle lobianchi. International Journal for Parasitology, 20, 747-753.

102. Tappenden T, Kearn GC. 1991. Crystalline bodies associated with spermatozoa in the vas deferens of the monogeneans Entobdella soleae and E. hipoglossi. Parasitology Research, 77, 421-424.

103. Tappenden T, Kearn GC. 1991. Spermiogenesis and sperm ultrastructure in the monocotylid monogenean parasite Calicotyle kroyeri. International Journal for Parasitology, 21, 57-63.

104. Tuzet O, Ktari M-H. 1971. La spermiogenèse et la structure du spermatozoïde de Microcotyle mormyri Lorenz, 1878 (Monogenea). Comptes Rendus de l'Académie des Sciences (Paris) Série D, Sciences Naturelles, 272, 2702-2705.

105. Tuzet O, Ktari M-H. 1971. Recherches sur l'ultrastructure du spermatozoïde de quelques Monogènes. Bulletin de la Société Zoologique de France, 96, 535-540.

106. Watson NA, Chisholm LA. 1998. Spermatozoa and spermiogenesis in the monocotylid Heterocotyle capricornensis (Platyhelminthes, Monogenea, Monopisthocotylea), including observations of aberrant folding and fusing of spermatozoa in one individual. Folia Parasitologica (Praha), 45, 211-220.

107. Watson NA, Rohde K. 1992. Ultrastructure of sperm and spermatogenesis of Anoplodiscus cirrusspiralis
(Platyhelminthes, Monogenea, Monopisthocotylea). Annales de Parasitologie Humaine et Comparée (Paris), $67,131-140$.

108. Watson NA, Rohde K. 1994. Ultrastructure of sperm and spermiogenesis in the monocotylid monogeneans Monocotyle helicophallus and Calicotyle australiensis (Platyhelminthes). International Journal for Parasitology, 24, 1019-1030.

109. Watson NA, Rohde K. 1995. Ultrastructure of spermiogenesis and spermatozoa of Neopolystoma n. sp. (Platyhelminthes, Monogenea, Polyopisthocotylea, Polystomatidae). Parasitology Research, 81, 343-348.

110. Watson NA, Whittington ID, Rohde K. 1995. Ultrastructure of spermiogenesis and spermatozoa in the monogeneans Concinnocotyla australensis (Polystomatidae) and Pricea multae (Gastrocotylidae). Parasite, 2, 357-366.

111. Ye F, King SD, Cone DK, You P. 2014. The mitochondrial genome of Paragyrodactylus variegatus (Platyhelminthes: Monogenea): differences in major non-coding region and gene order compared to Gyrodactylus. Parasites \& Vectors, $7(1), 377$.

112. Zhang D, Zou H, Wu SG, Li M, Jakovlić I, Zhang J, Chen R, Wang GT, Li WX. 2017. Sequencing of the complete mitochondrial genome of a fish-parasitic flatworm Paratetraonchoides inermis (Platyhelminthes: Monogenea): tRNA gene arrangement reshuffling and implications for phylogeny. Parasites \& Vectors, 10(1), 462.

113. Zhang D, Zou H, Wu SG, Li M, Jakovlić I, Zhang J, Chen $\mathrm{R}$, Wang GT, Li WX. in press. Sequencing, characterization and phylogenomics of the complete mitochondrial genome of Dactylogyrus lamellatus (Monogenea: Dactylogyridae). Journal of Helminthology, doi: 10.1017/ S0022149X17000578.

114. Zhang J, Wu X, Xie M, Li A. 2012. The complete mitochondrial genome of Pseudochauhanea macrorchis (Monogenea: Chauhaneidae) revealed a highly repetitive region and a gene rearrangement hot spot in Polyopisthocotylea. Molecular Biology Reports, 39(8), 81158125 .

Cite this article as: Justine J-L, Poddubnaya LG. 2018. Spermiogenesis and spermatozoon ultrastructure in basal polyopisthocotylean monogeneans, Hexabothriidae and Chimaericolidae, and their significance for the phylogeny of the Monogenea. Parasite 25, 7

Reviews, articles and short notes may be submitted. Fields include, but are not limited to: general, medical and veterinary parasitology; morphology, including ultrastructure; parasite systematics, including entomology, acarology, helminthology and protistology, and molecular analyses; molecular biology and biochemistry; immunology of parasitic diseases; host-parasite relationships; ecology and life history of parasites; epidemiology; therapeutics; new diagnostic tools.

All papers in Parasite are published in English. Manuscripts should have a broad interest and must not have been published or submitted elsewhere. No limit is imposed on the length of manuscripts.

Parasite (open-access) continues Parasite (print and online editions, 1994-2012) and Annales de Parasitologie Humaine et Comparée (1923-1993) and is the official journal of the Société Française de Parasitologie. 